\title{
Technology Development for the Design of Waste Repositories at Arid Sites: Field Studies of Biointrusion and Capillary Barriers
}

\author{
John W. Nyhan \\ Willy Abeele \\ Tom Hakonson \\ Edward A. Lopez
}

\section{DISCLAIMER}

\begin{abstract}
This report was prepared as an account of work sponsored by an agency of the United States Government. Neither the United States Government nor any agency thereof, nor any of their employees, makes any warranty, express or implied, or dssumes any legal liability or responsibility for the accuracy, completeness, or usefulness of any information, appardtus, product, or process disciosed, or represents that its use would not infringe privately owned rights. Reference herein to any specific commercial product, process, or service by trade name, tra demark, manufacturer, or otherwise does not necessarily constitute or imply its endorsement, recommendation, or favoring by the United States Government or any agency thereof. The vicws and opinions of authors expressed herein do not necessarily state or reflect those of the United States Governmeni or any agency thereof.
\end{abstract}

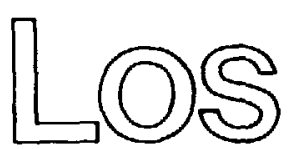




\title{
TECHNOLOGY DEVELOPMENT FOR THE DESIGN \\ OF WASTE REPOSITORIES AT ARID SITES: \\ FIELD STUDIES OF BIOINTRUSION \\ AND CAPILLARY BARRIERS
}

\author{
by \\ John W. Nyhan, Willy Abeele, Tom Hakonson, and \\ Edward A. Lopez
}

\begin{abstract}
The field research program involving the development of technology for arid shallow land burial (SLB) sites is described. Results of field testing of biointrusion barriers installed at an active low-level radioactive waste disposal site (Area G) at Los Alamos are presented. A second experiment was designed to test the ability of a capillary barrier to effectively convey water infiltrating a SLB trench around and away from underlying buried wastes. The performance of the capillary barrier was tested in the field for a Darrier of known thickness $(2 \mathrm{~m})$, slope (10\%), and slope length $(2 \mathrm{~m})$, and for one combination of porous materials [a crushed tuff-clay $(2 \% \mathrm{w} / \mathrm{w})$ mixture overlying Ottawa sand] subjected to a k: own water addition rate. The waste management implications of both studies are also discussed.
\end{abstract}

\section{INTRODUCTION}

The purpose of the Shallow Land Burial (SLB) Technology Development task of the National Low-Level Waste Management Program is to provide research for technology development to determine and quantify essential components of SLB integrated systems for optimal designs to control contaminant mobilization and migration at arid sites.

Reliable and comprehensive experimental data are just becoming available to allow analyses for design of SLB facilities at arid sites or to predict the future performance of proposed SLB designs. Additional analyses and information are needed to allow preparation of manuals to design SLB 
of an arid site predictive capability for SLB processes. Finally, the data and our interpretations will become part of a model validation data base available to the national program.

An important aspect of developing a validated and credible predictive capability is extensive testing and evaluation. These tests and evaluations are being done as part of field experiments presented in this report. The data collection and analysis activities presented in this report involve field experiments on biointrusion-barrier testing at an active low-level radioactive waste disposal area at Los Alamos, and on capillary-barrier testing for subsurface water management at waste burial sites.

\section{AREA G STUDY}

A. General Description and Waste Use History of Area G

The U. S. Geologicai Survey cooperated with the Atomic Energy Commission in the selection of Area $G$ and recommended that disposal pits be no closer than $15 \mathrm{~m}$ to the canyons, be no more than $15 \mathrm{~m}$ deep, and that open joints in the pits be sealed with fine-grained material. The area was selected because it is relatively isolated and probably is large encugh for disposal of solid wastes for 10 or more years. Area $G$ is currently being used for the disposal of radioactive wastes and is located on Mesita del Buey approximately $3.2 \mathrm{~km}$ southeast of the intersection of the access road and Pajarito Road (S 1/2 $\mathrm{sec}$. 31 T. 19 N., R. 7 E). Mesita del Buey is approximately $4.8 \mathrm{~km}$ south of the Los Alamos townsite. It is a narrow, southeast-trending mesa that is part of the Pajarito Plateau. Bounded by vertical cliffs with steep slopes at their base, the mese is as narrow as $91.4 \mathrm{~m}$, as wide as $402 \mathrm{~m}$, and is approximately $3.2 \mathrm{~km}$ long. Mesita del Buey is about $30.5 \mathrm{~m}$ above the Pajarito Canyon floor at its western margin and less than $24.4 \mathrm{~m}$ above the canyon floor at its 
eastern end. The surface slopes gently to the southeast from an altitude of $2103 \mathrm{~m}$ to $2012 \mathrm{~m}$. Soil cover along the axis is 0.3 to $0.6 \mathrm{~m}$ thick and thins toward Pajarito Canyon on the south and Canada del Buey on the north.

The zone of saturation (water table) lies at unknown depth beneath Area $G$ (Rogers 1977). It is at a depth greater than $100.6 \mathrm{~m}$. The depth to water at local well PM-2 [elevation $2046.7 \mathrm{~m}$ ] was $250.9 \mathrm{~m}$. Water is perched seasonally in the alluvium in Pajarito Canyon.

Until 1971, no attempt to segregate waste by pit was made. Pits received nonroutine and routine radioactively contaminated waste. All pits were initially used for nonroutine waste followed by a mixture of routine and nonroutine waste. Nonroutine contaminated waste included debris from the demolition of TA-l and Bayo Site, classified materials, and pieces of heavy equipment such as dump trucks. Routine contaminated waste consisted of cardboard boxes $(33 \mathrm{~cm} \times 33 \mathrm{~cm} \times 61 \mathrm{~cm}), 5-\mathrm{mil}$ plastic bags $(33 \mathrm{~cm} \times 61 \mathrm{~cm}$ and $256 \mathrm{~cm} \times 61 \mathrm{~cm})$ of material generated in the chemistry laboratories, and $0.20-m^{3}$ barrels of sludge from the waste treatment plants at Building 35 DP-West, TA-45 and TA-50.

A December 1970 radionuclide inventory states (Rogers 1977) the following:

The following report is based on all available $\mathrm{H}-1$ records for radioactive waste buried at Los Alamos. From many entries in the $\mathrm{H}-1$ records, the amount and type of radioactive materials are listed as Classified (SECRET/RD). Because of entries such as these, and also other similar ones, this report is an audit of $\mathrm{H}-\mathrm{l}$ records and not an investigation of complete facts. Group $\mathrm{H}-\mathrm{l}$ records from 1945 through 1960 have almost no information concerning what radioactive material or how much in gram quantities. These records were of the monitoring results of radioactive material or contaminated materials. These records also inclujed volume of waste, iocation of waste, date of the burial, signatures of persons invalved, and from which group the material originated. Area G has 50007 lbs [22682.8 kg] of $\mathrm{D}-38,9034 \mathrm{~g}$ of $\mathrm{U}-235,1084 \mathrm{~g}$ of $\mathrm{Pu}-239,0.204 \mathrm{~g}$ of $\mathrm{Pu}-238,0 \mathrm{~g}$ of $\mathrm{U}-233$ and less than $10 \mathrm{~g}$ of tritium. 
The next radionuclide inventory was published May 1974 (Rogers 1977) and

states:

The records describing the material placed in these pits generally do not contain information on the curie content of the material, but the isotopic composition is generally indicated. Uranium- and plutonium-contaminated wastes are placed in separate pits. Americium-241 is known to be present in the pits, occurring in association with plutonium in drums of sludge generated by liquid treatment facilities. A reliable estimate can be made of the curie content of the various isotopes using material accountability data. Other radioisotopes, such as tritium, are known to be present in the disposal pits in unknown quantities. Recurds on the type and activity of wastes placed in disposal shafts are generally quite good.

Currently, low-level radioactive solid waste materials continue to be disposed of at Area G in SLB pits. Engineering Drawing ENG-C 18463 (Materials Waste Pits Standard Specifications, Mesita del Buey, TA-0), dated February 26, 1957, shows a pit in plan view, in longitudinal cross section, and in cross section at rigint angles to the axis of the pit. Pits were to be $182.9 \mathrm{~m}$ (maximum where possible) long and $30.5 \mathrm{~m}$ wide. One ramp of the pit was to have a 6:1 slope, and the other ramp was to have a $4: 1$ slope. The up ramp, a 6:1 slope, covers an approximate horizontal distance of $45.7 \mathrm{~m}$; the down ramp, a $4: 1$ slope, covers an approximate horizontal distance of $30.5 \mathrm{~m}$. A 7.6-m depth is shown for the pit with a note stating "actual depth will be determined by conditions encountered in the field." The walls of the pit were to be cut "as nearly vertical" as excavating equipment will permit (Rogers 1977).

B. Bicintrusion Barrier Study at Area G 1. Experimental Plan and Techniques. The Laboratory's low-level waste operations group, in the process of closing out a trench at Area $G$ in late 1981, provided the opportunity to install an intermediate-scale biointrusion experiment on the site. In order to address some of the issues 
raised by the small-scale lysimeter study (Hakonson 1985), an experiment was designed to monitor the performance of several trench cap designs with respect to plant root intrusion and percolation of water into the trench backfill.

The use of rock materials in intrusion-barrier designs leads to questions about the effects of such materials on water balance. Obviously, replacing a layer of crushed tuff within the trench cap with an equal depth of rock greatly reduces the soil moisture storage capacity of the cap. Consequently, the amount of water that eventually percolates through the cover and into the trench backfill may be increased, given that no special consideration is given to the lost moisture-storage capacity. One method of replacing lost storage. capacity would be to increase topsoil depth over the rocks. However, in order to produce observable treatment effects over the short life of the Area $G$ study, topsoil depths over the barriers were purposefully applied at less than optimum depth.

Four plots, $6 \mathrm{~m} \times 12 \mathrm{~m}$ each, were constructed (Fig: 1) on trench 25 at Area $G$ and consisted of $1 \mathrm{~m}$ of four different barrier configurations covered with only $15 \mathrm{~cm}$ of Hackroy series topsoil (Fig. 1). Although the 15-cm topsoil depth provided relatively little soil-moisture storage capacity (about $6 \mathrm{cln}$ of water at saturation), it did increase the probability of root intrusion and of percolation occurring into and through the various intrusionbarrier materials for purposes of determining the characteristics and magnitude of these failure modes. Thus, any precipitation event that resulted in greater than $6 \mathrm{~cm}$ of infiltration into the topsoil had a high probability of water percolating into the biobarrier and, in the case of the rock barrier systems with little water storage capacity, into the underlying backfill.

One plot, which served as a control, approximated the current practice of applying a trench cap of $1 \mathrm{~m}$ of crushed tuff covered with $15 \mathrm{~cm}$ of topsoil. 
The other three plots consisted of various combinations of cobble and gravel coverea with $15 \mathrm{~cm}$ of topsoil (Fig. 1). A 4-5\% surface slope provided for some surface runoff.

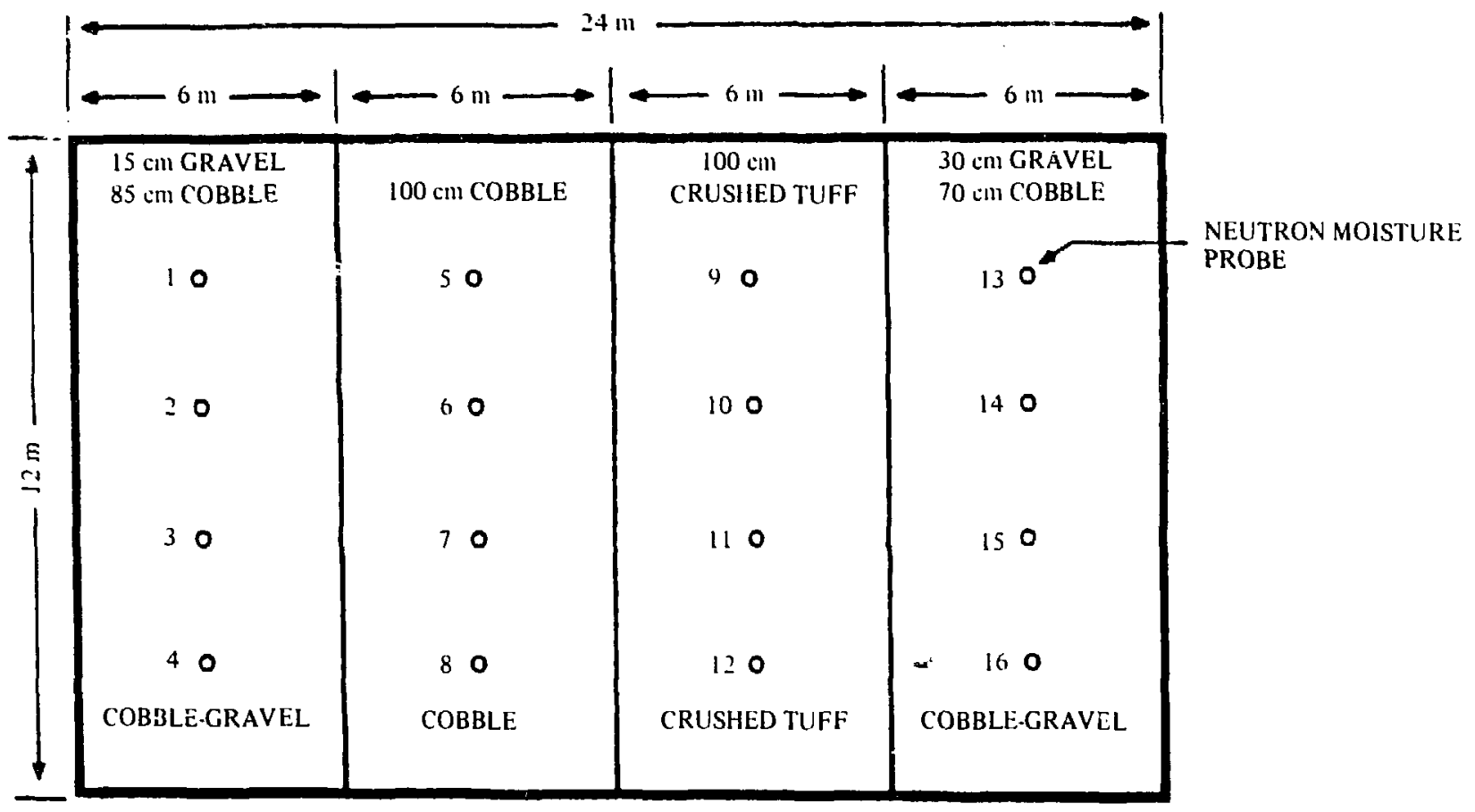

Fig. 1. Intermediate-scale biointrusion-barrier experiment at Area G.

Galvanized roofing material was used to delineate plot boundaries (Fig. $2)$ in order to facilitate plot construction and to prevent soil water interflow between plots. Neutron moisture gauge access tubes were installed to a depth of $30 \mathrm{~cm}$ into the backfill underlying the cap designs to allow for the monitoring of soil moisture in the backfill. Cesium chloride was applied at a rate of $30 \mathrm{~g} / \mathrm{m}^{2}$ to the backfill surface to serve as a plant-available simulated waste for evaluating root intrusion. The plots were then filled 


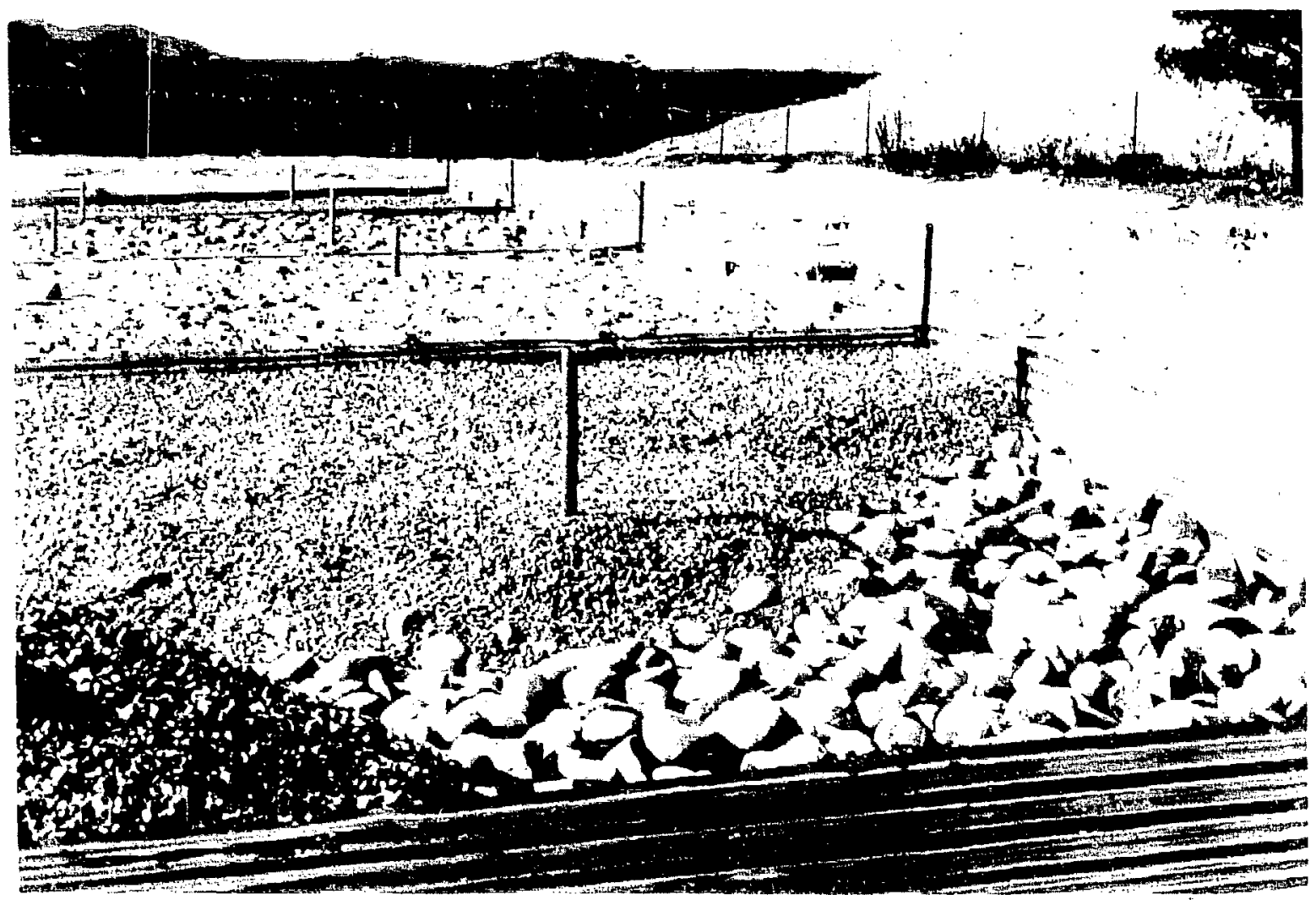

Fig. 2. Four biointrusion-barrier plots under construction on trench 25 at Area $G$ in 1981. Galvanized metal plot borders, neutron access tubes, and portions of the barrier materials are shown as they were before the final $15 \mathrm{~cm}$ of topsoil was àdded.

with the appropriate barrier material (Fig. 2) and topsoil before seeding with a seed mixture of nine native grass species (Hakonson 1986).

Soil moisture in the backfill underlying the caps was measured with a Campbell Pacific model 503DR neutron moisture gauge to provide an indirect measure of percolation. In the control plot, changes in soil water content 
were monitored at depths of $92,107,122$ and $137 \mathrm{~cm}$, and the water content at the $137-\mathrm{cm}$ depth was monitored with respect to time in the biobarrier plots. Vegetation samples (five/plot/sampling period) were collected periodically throughout the study and analyzed for cesium using neutron activation analysis. The only water added to the plots was natural precipitation.

2. Results and Discussion of Area G Study. In general, cesium concentrations in all samples averaged less thari background levels of $1 \mathrm{ppm}$ or less through November 8, 1983 (Hakonson 1986), although concentrations in individual samples from the plot with $100 \mathrm{~cm}$ of crushed tuff measured as high as $83 \mathrm{ppm}$, or about 100 times background. Only two of the intrusion-barrier designs (one using $100 \mathrm{~cm}$ of cobble and one using $30 \mathrm{~cm}$ of gravel over $70 \mathrm{~cm}$ of cobble) proved to be essentially $100 \%$ effective in preventing root penetration into the cesium layer during this 18 -month study period. A relatively high percentage $(15-20 \%)$ of the samples from the soil-crushed tuff and soil-gravel/cobble ( $15 \mathrm{~cm}$ gravel $-85 \mathrm{~cm}$ cobble) plots exhibited higher than background levels of cesium. Samples collected from August 29, 1983, through November 8, 1983 (toward the end of the second growing season), on the control treatment (soil-crushed tuff) were definitely showing that plant roots had grown into the cesium layer: $47 \%$ of the 15 samples collected during this period had above-background cesium concentrations. The rock barriers were very effective in preventing roots from penetrating the cesium layer during this time interval: only 1 sample out of 45 showed elevated cesium concentrations.

Data are available on the cesium content of the grass species that dominated the cover through 1985 . The results through July 3, 1984, do indicate that the biobarriers were continuing to perform satisfactorily. Over 
$80 \%$ of the plant samples collected on the control plot from December 12, 1983, through July 3, 1984, demonstrated above-background cesium concentrations as high as $206 \mathrm{ppm}$, indicating that the plant roots were well established in the cesium layer after the third growing season. Plant samples collected on August 12, 1985, showed similar results: below-background levels of cesium were found in all samples collected above the rock bairiers, whereas $40 \%$ of the control plot samples had elevated cesium concentrations at the end of the fourth growing season.

Time series measurements of soil moisture taken about $30 \mathrm{~cm}$ into the backfill (137-cm depth) underlying the four cap designs are presented in Fig. 3 for the time period starting in 1982 through the first half of 1984 (see Appendix A for more detail). Each value presented here represents the average water content of all four access tubes in each plot (Fig. 1) for each depth and sampling date.

Important features of the data in Fig. 3 are that percolation of water through all four cap designs occurred several times over the 31-month observation period and that backfill soil moisture generally increased with time following a step-function pattern. Several sharp increases in backfill moisture coincided with precipitation events and, in particular, snowmelt during mid to late winter. Backfill moisture during the summer growing season was relatively constant or decreased slightly despite the occurrence of several large summer rainstorms, which, on the average, deposit about $75 \%$ of the annual precipitation at Los Alamns. That suggests that even though very little moisture storage capacity was available in the $15 \mathrm{~cm}$ of topsoil, the capacity, when coupled with the large losses of soil water to evapotranspiration, was sufficient to prevent percolation into the backfill. Hoviever, during winter, when plant transpiration was essentially zero and evaporation 


\section{LOS ALAMOS LOW-LEVEL WASTE DISPOSAL SITE}

(AREA G)

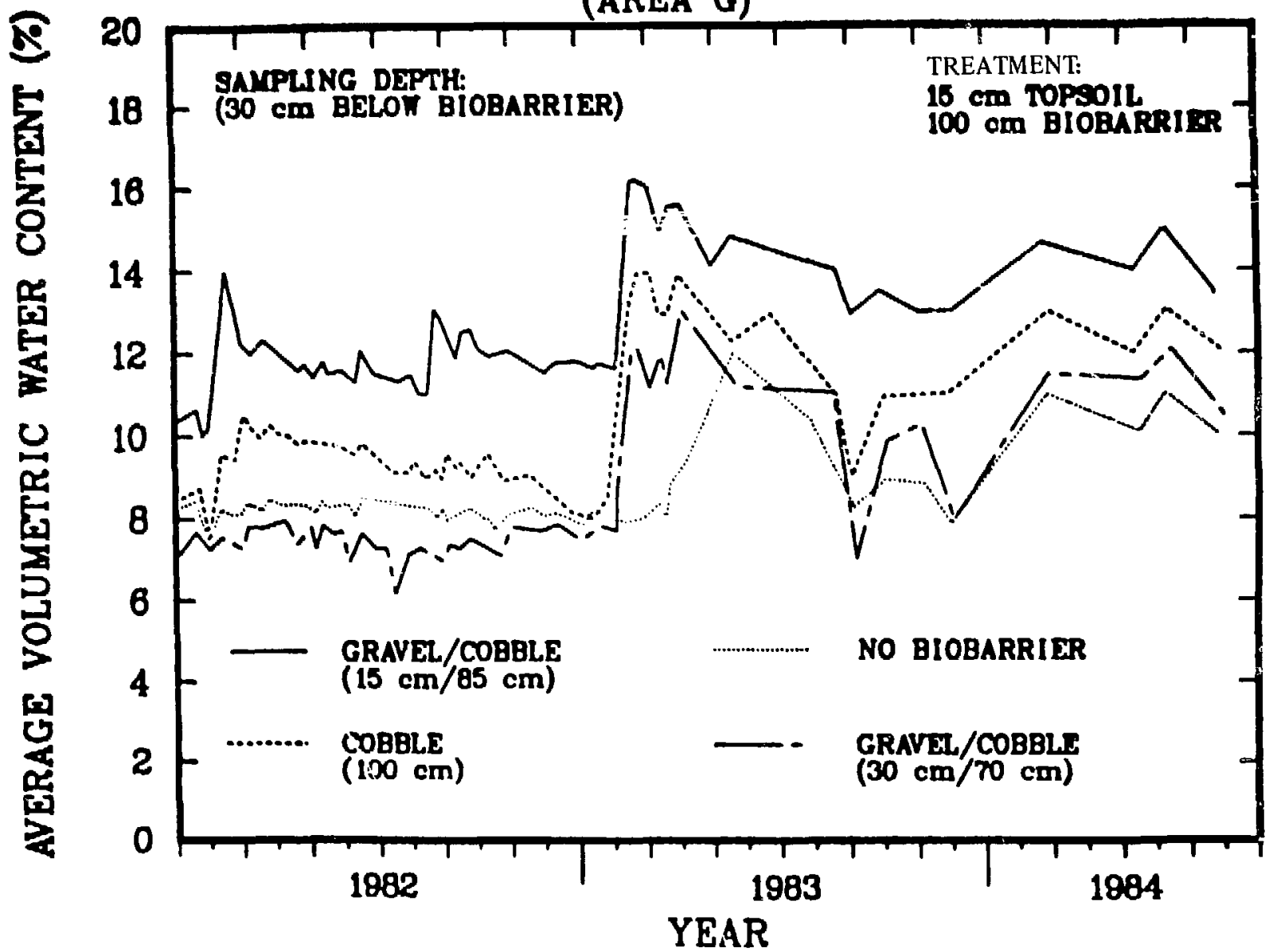

Fig. 3. Volumetric water content of backfill under the biointrusion-barrier study $\mu$ ? nts at Area $G$.

from the soil surface was greatly reduced, percolation did occur and was followed by a commensurate rise in backfill moisture.

More recent soil water data are presented in Fig. 4 for the time period from February 21, 1984, through August 13, 1985. In the plot with the crushed-tuff treatment, the water content of all four depths remained essentially constant in 1984 until November 6 (Fig. 4), indicating very little 
percolation [snowmelt (January through March) and rain (July through August)] of precipitation into the profile. However: the next 6 -month period was more than $240 \%$ wetter than normal for Los Alamos. The water content dramatically increased at all sampling depths in the crushed tuff from about $5-10 \%$ on October 17, 1984 (Fig. 4), to about $18-20 \%$ on May 14, 1985.

The three biobarrier treatments invoiving gravel and cobble demonstrated higher water-content values (about $30 \mathrm{~cm}$ beneath the biobarrier) with time than similar values for the crushed-tuff treatment (Fig. 4). This observation reflects the loss of water storage capacity in the 1 -m-thick layer of gravel and/or cobble that would otherwise be present in the corresponding 1-m-thick layer of crushed tuff in this experiment. This point is further demonstrated by comparing the vertical distributions of water measured in these plots at the end of this very wet season in late April, 1985 (Figs. 5-8). The volumetric water content in the gravel-cobble biobarriers remains at 4-5\% (Figs. 5-7), whereas the water cortent in the tuff, at a similar sampling depth, ranges from $8-14 \%$ (Fig. 8).

This loss of water-holding capacity in the rock barrier designs cari obviously result in significantly greater percolation of precipitation ard, concurrently, more rapid changes in soil water content (Fig. 4). This effect is most apparent under the very wet conditions occurring at the end of snowmelt and the late winter rainstorms in 1985 and under the cobble biobarrier. Thus, the water content $30 \mathrm{~cm}$ under the cobble biobarrier went from $19 \%$ on May 14 (Fig. 4) to $26 \%$ on May 22 and then to $17 \%$ on May 30 . This trend also indicates that many of the pockets of topsoil between the individual rocks at the top of the cobble biobarrier became saturated after May 14 , resulting in a surge of water percolating into the underlying tuff layer (Fig. 4). 

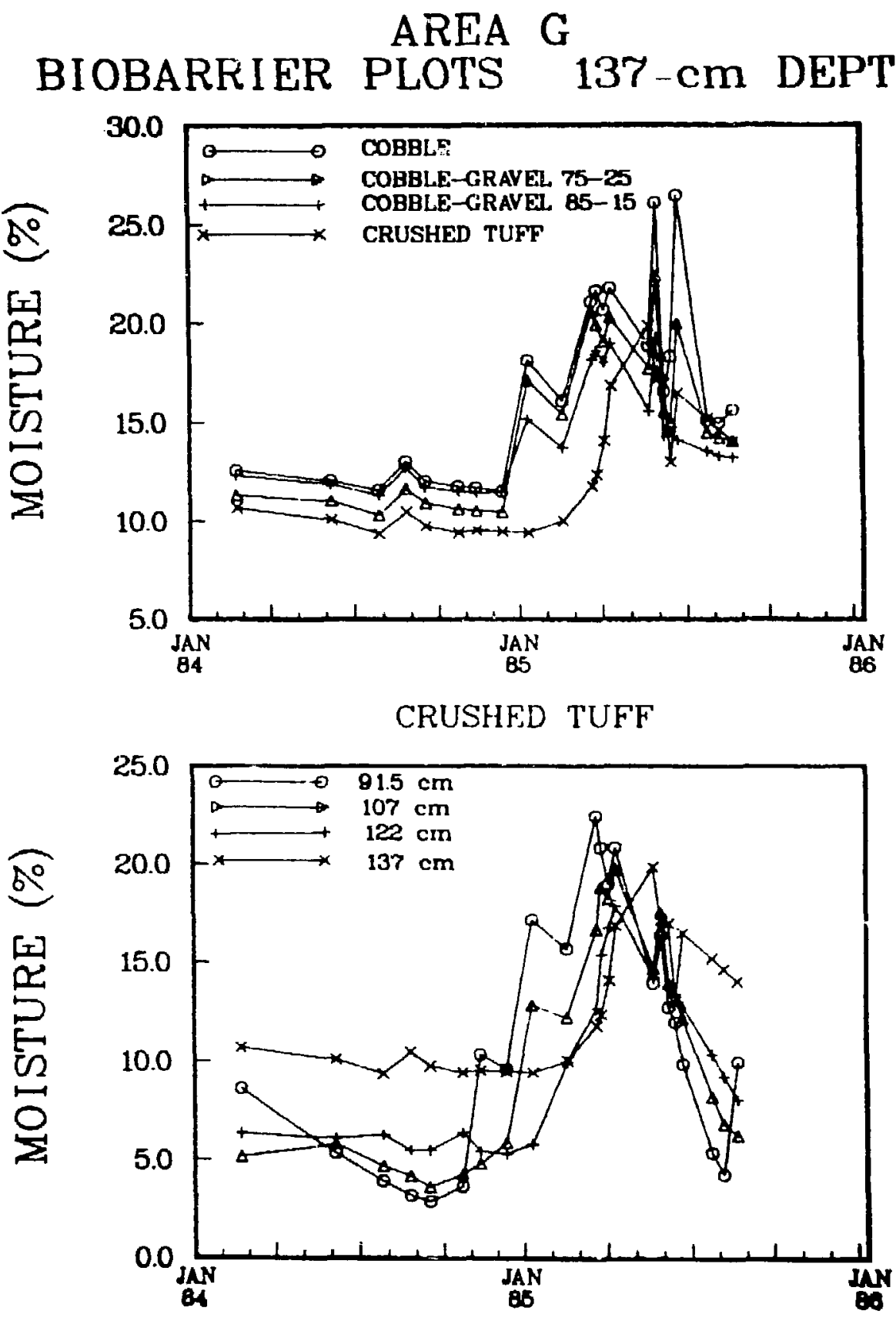

Fig. 4. Distribution of water in the tuff at Area G versus time in 1984 and 1985. 


\section{AREA "G" - PLOT NO.1, COBBLE-GRAVEL PERCENT MOISTURE BY VOLUME}

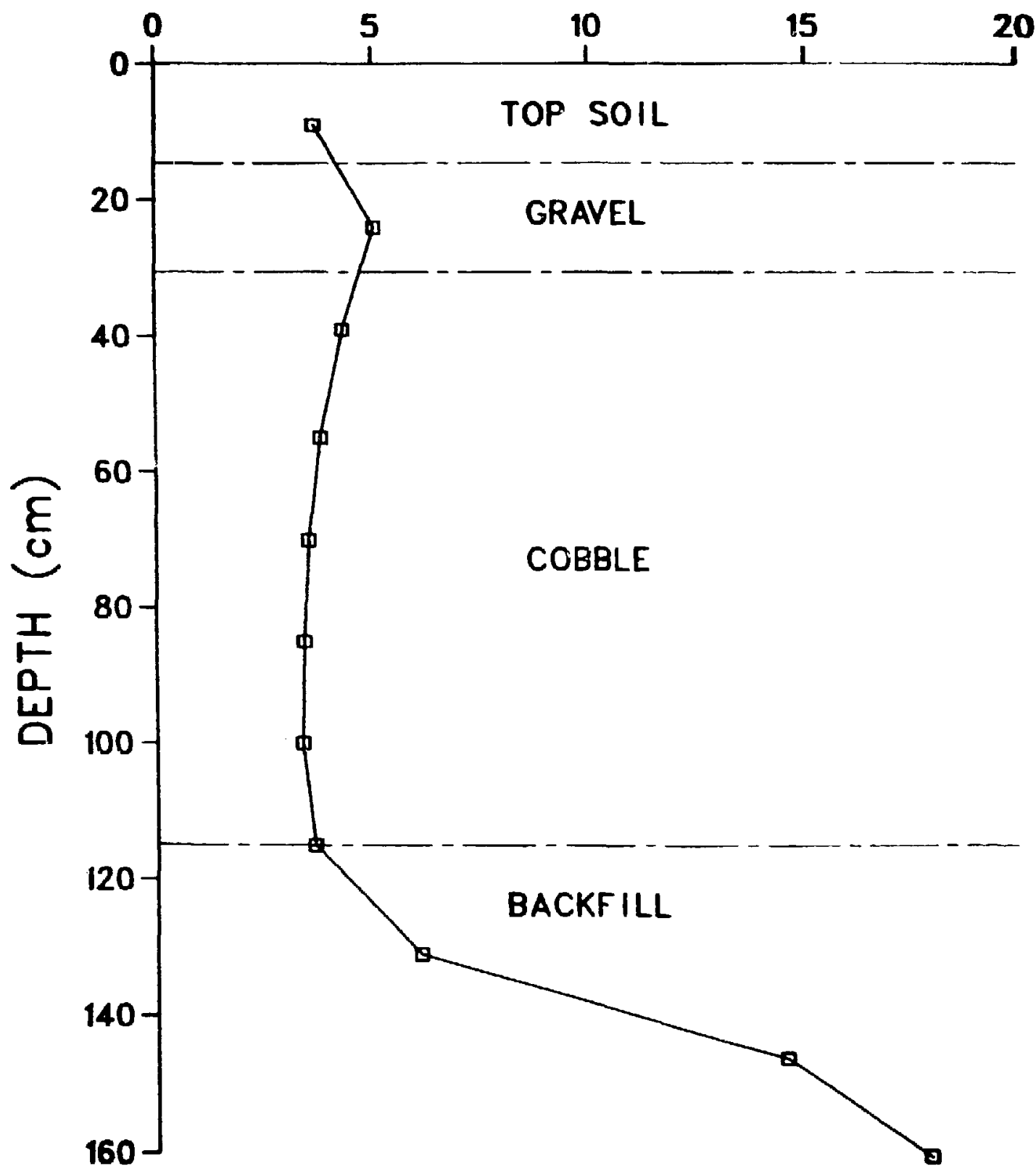

Fig. 5. Distribution of volumetric water content as a function of sampling depth at Area $G$ at the end of April 1985 (15 cm gravel/85 cm cobble). 


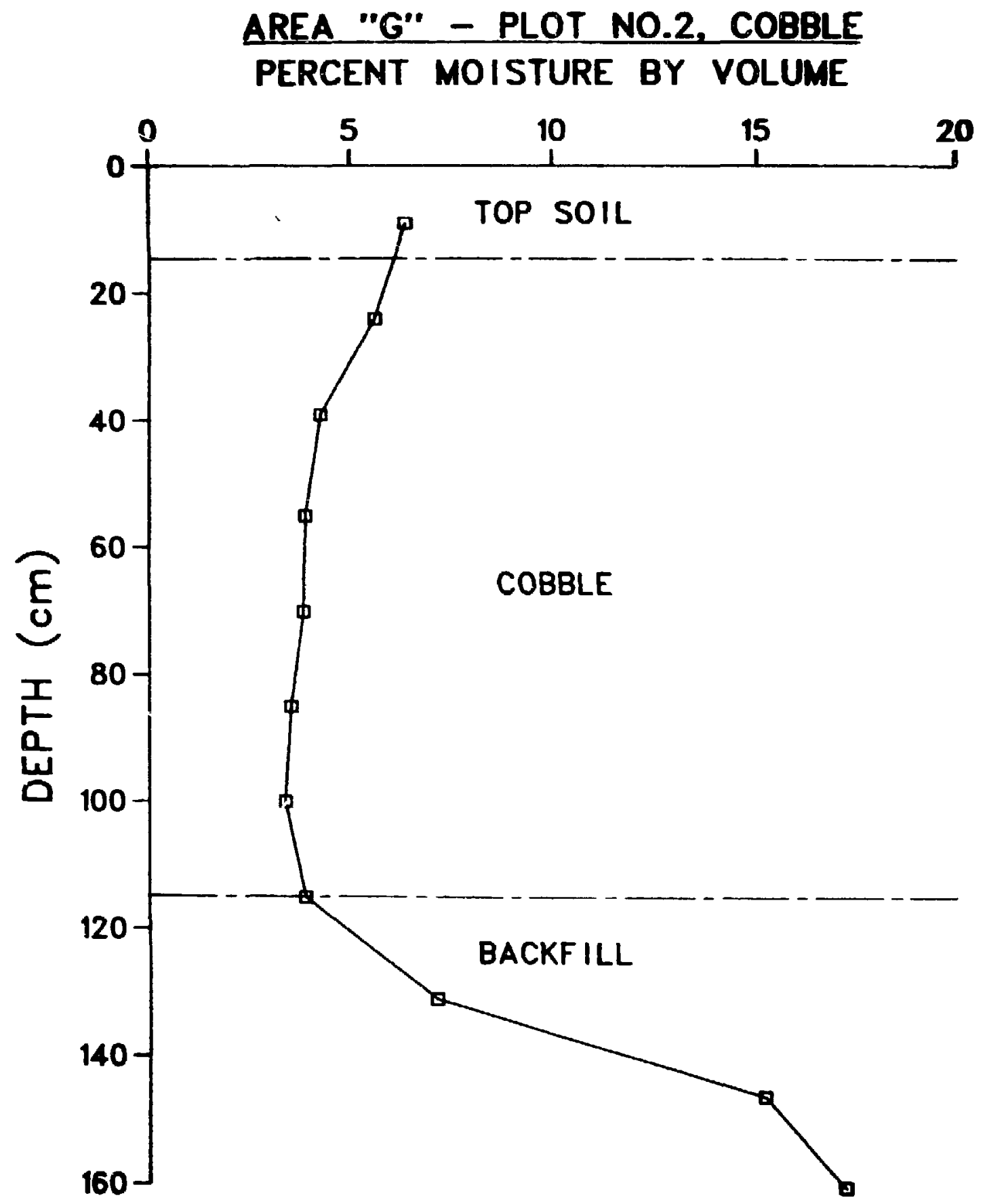

Fig. 6. Distribution of volumetric water content as a function of sampling depth at Area G at the end of Aprif 1985 (100 cm gravel). 


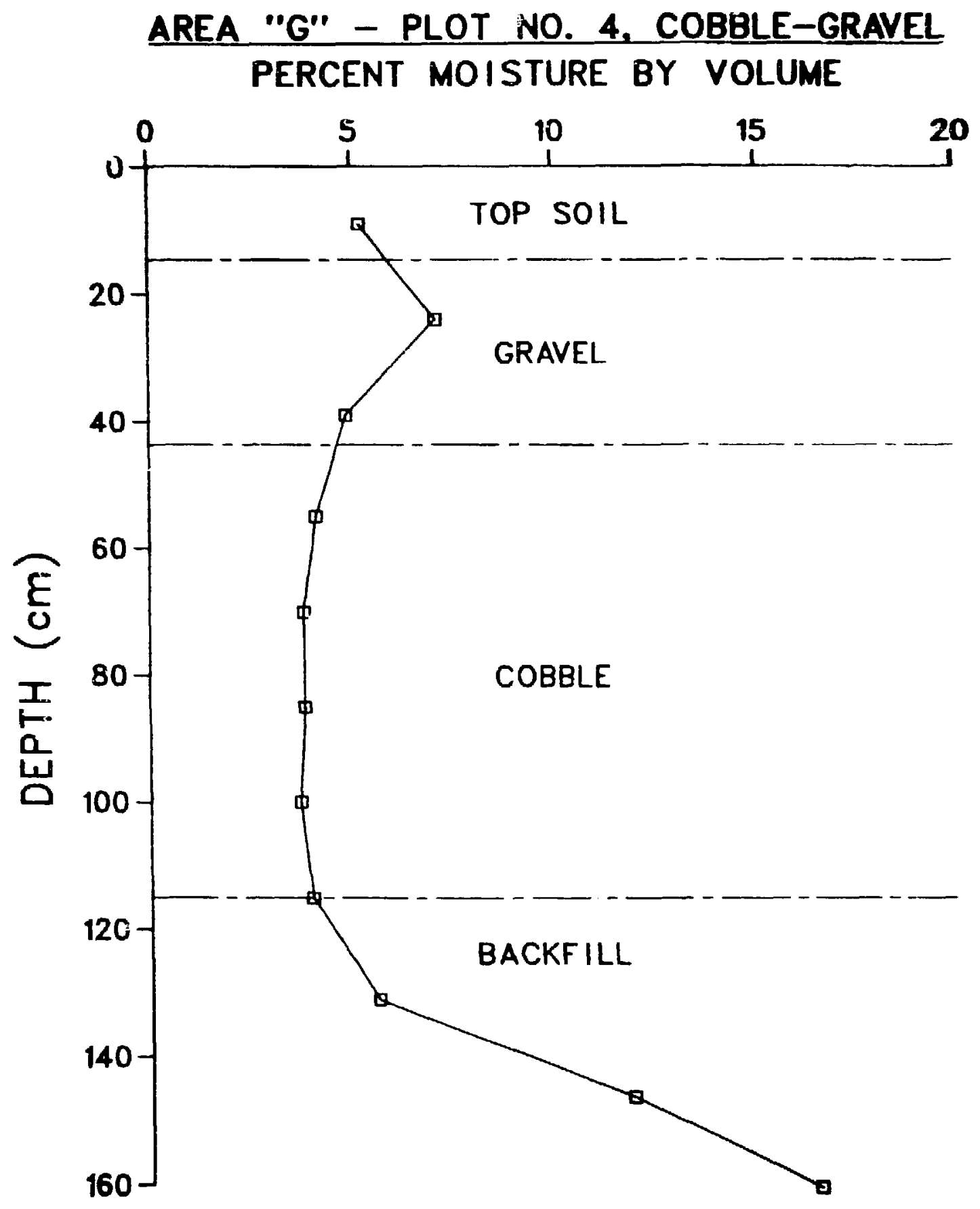

Fig. 7. Distribution of volumetric water content as a function of sampling depth at Area G at the end of April 1985 (30 $\mathrm{cm}$ grave $1 / 70 \mathrm{~cm}$ cobble). 


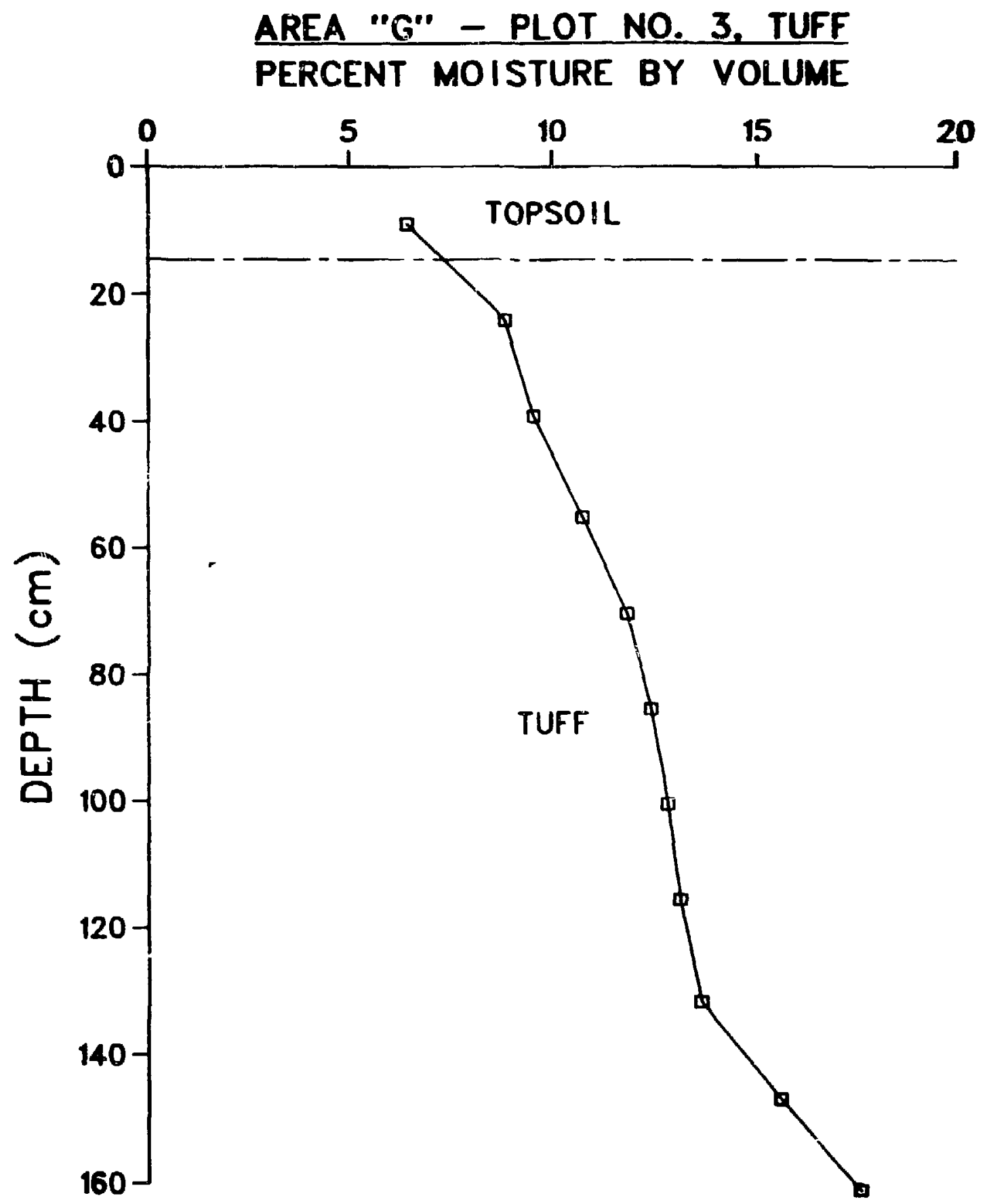

Fig. 8. Distribution of volumetric water content as a function of sampling depth at Area $G$ at the end of April 1985

(100 cm tuff control plot). 
In summary, the moisture content of backfill beneath the rock barrier designs responded rapidly to water percolating out of the topsoil because of the low storage capacity and high hydraulic conductivity of the rock material. In contrast, changes in the water content of backfill beneath the crushed-tuff cap design were relatively insensitive to precipitation inputs because of the added storage capacity and lower hydraulic conductivity of the crusned-tuff barrier material. Although ceasonal patterns in the moisture content of the backfill under all cap designs were evident, the overall pattern suggests one of increasing moisture with time. In general, backfill moisture in all plots had increased by $2-4 \%$ by mid-i984 over that measured at the beginning of the study. The soil water content in the backfill beneath the biobarriers almost doubled in value after the sncwmelt and late spring rainstorms in 1985 (Fig. 4) and then decrea. $F^{\prime}$ as the water gradually moved into the below-lying layers of backfill in trench 25 .

Further monitoring of backfili moisture beneath the 137-cm depth and hydrologic modeling studies would be necessary to understand the full impact of the water infiltrating this SLB trench. However, it does appear that when a wet winter/spring season occurs at Los Alamos, some water does infiltrate the trench cap, and under these conditions, the rock biobarriers do seem to perform successfully in preventing roots from penetrating the waste materials buried beneath them.

\section{CAPILLARY BARRIER STUDY}

A. Introduction

The purpose of our experiments with capillary barriers is to field-test systems that can be used to controi the movement of water on top of and around SLB trenches. These systems will insure the execution of the performance 
objectives for low-level radioactive waste disposal sites set up by the Nuclear Regulatory Commission (NRC) and by the DOE.

Small-scale modeling has demonstrated it is possible, by using capiliary barriers, to maintain dry structures in porous media. Barriers are created by differences in particle size and are effective because suction predominates over gravity forces. The percolating liquid will penetrate the coarser material only after the overlying finer materials are near saturation. Consequently, the structure, which is enclosed in the coarser material, remains dry. As long as the pressure at the coarse/fine interface remains negative, water infiltrating the finer layer will not cross the interface but will flow laterally within the finer layer; percolation occurs where the saturated water front reaches the edge of the coarse laver. The limiting granulometric differences beyond which this phenomenon ceases to exist have been determined. This barrier concent has sometimes been referred to as the "wick effect." It was found that under saturated conditions a gravel lens caused lateral flow in a finer-textured overlying material. The lateral distance over which the water can be transported is limited and will be influenced by the slope of the interface.

At equal matric potentials, a fine-grained medium will contain more water than a coarse-grained medium. During drainage, an initially saturated soil will drain its largest pores first, whereas in wetting a dry soil, the smallest pores will fill first as the matric potential is allowed to increase (getting less negative); the wate- content increases as progressively larger pores are filled. This will be accompanied by an increase in hydraulic conductivity and lateral diversion of water already promoted by the presence of a sloping surface. The coarser medium, on the other hand, with its predominant?y large pores will remain relatively dry with a low hydraulic 
conductivity until the matric potential reaches zero and near zero at the interface (Figs. 9 and 10). The systems will fail when or before the matric potential at the interface ceases to be negative. Point readings at the interface are provided through tensiometers. Proximity of the failure point to zero will be the function of abruptness and magnitude of particle size difference at the interface.

Our wick-system designs indicate that an effective wick system is one where the suction at the wick interface is about $4 \mathrm{kPa}$ tension or less before failure (Abeele and DePoorter 1984). To obtain such a low suction between our backfill and sand, the addition of a small amount of bentonite to the backfill materials at our land disposal site is necessary (Fig. 11), resulting in a major change in saturated hydraulic conductivity with only small amounts of clay added (Ábeele 1984a).

The geotechnical aspects of Fig. 11 are important to waste management site designs because permeability is the dominant parameter in the design and implemencatisn of waste disposal facilities. Clay is prominent among the materials usually considered to line or cap disposal pits. Foremost among the problems connected with the use of clays is cracking during periods of desiccation, although both the Environmental Protection Agency (EPA) and the NRC seem to feel that clays, as barriers to water leachate migration and inflow of water, are the principal materials to be considered as liners and caps in waste disposal facilities. Clays and soils, in general, also offer by far the longet service life of any liner material.

Use of clay mixes instead of pur c clays may be warranted but not solely on the basis of economics; mechanical benefits may even become overriding in mandating the use of mixes. In Los Alamos, New Mexico, the use of local tuff with low amounts of bentonite appeared to be very promising in greatly 


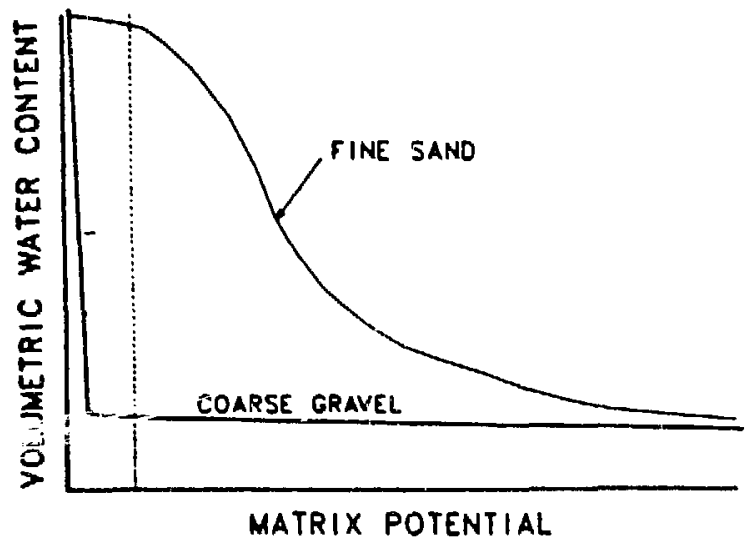

Fig. 9. Hypothetical wetting curve for a fine sand and a coarse gravel.

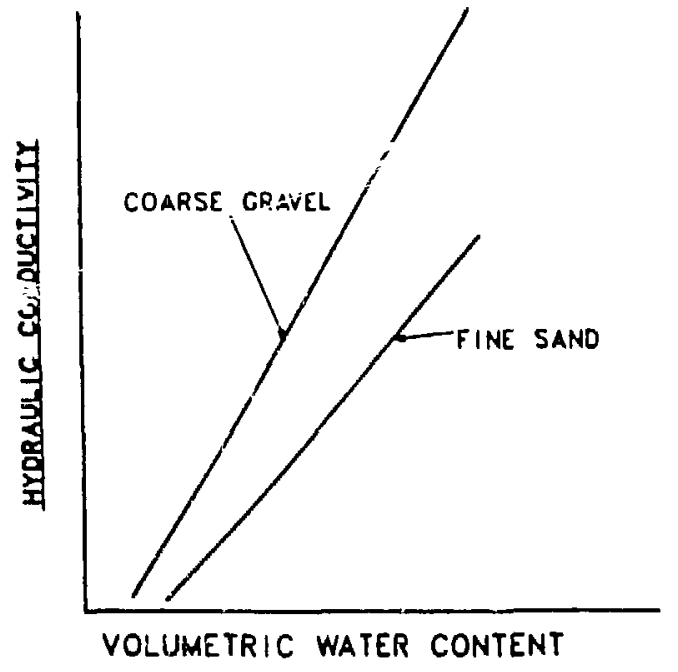

Fig. 10. Hypothetical $K(\theta)$ curves for a fine sand and a coarse gravel.

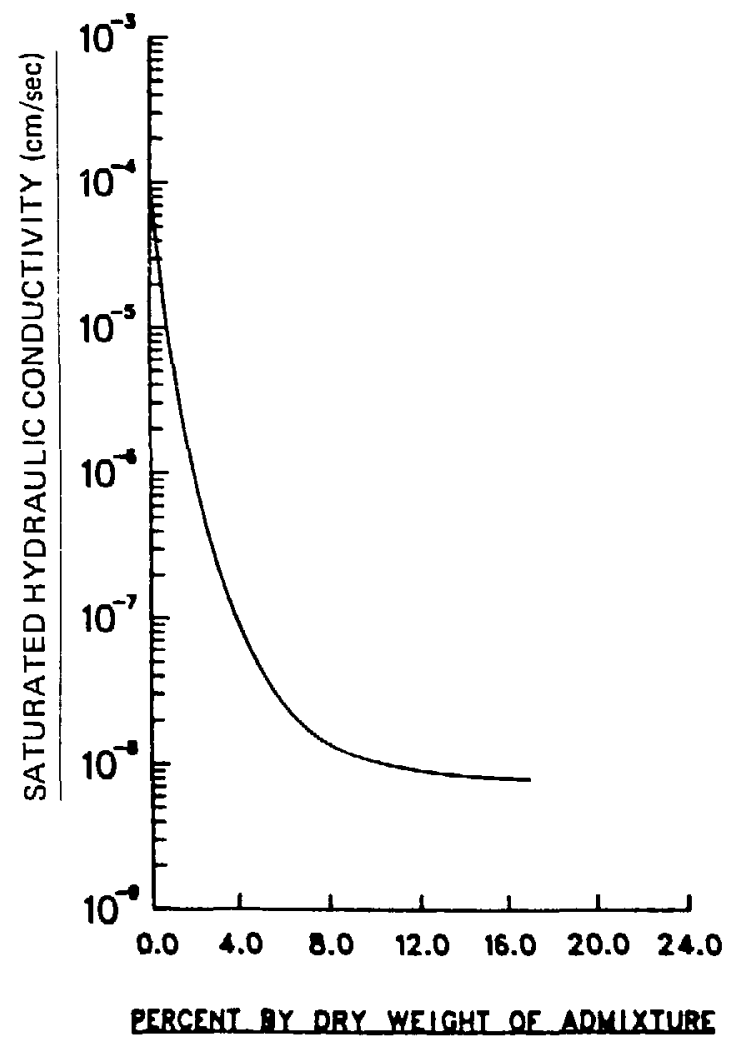

Fig. 11. Effects of adding bentonite to Los Alamos tuff. 
decreasing hydraulic conductivity without showing any of the mechanical impairments of clays (Abeele 1984a). Saturated sodium bentonite absorbs water up to 5 times its own mass to form a gel up to 15 times its own dry volume. Besides being less expensive, a liner or cap, consisting of a mix of the local medium and bentonite clay, would probably not crack when desiccated. Cracking from desiccation can be further minimized by proper compaction. A low hydraulic conductivity, combined with acceptable mechanical characteristics, should be obtainable at some ideal mix of two materials, each possessing one or the other property.

\section{B. Experimental Design and Techniques}

Our field experiment was designed to test the performance of a wick system emplaced in a 6.1-m-deep caisson with a diameter of $3.05 \mathrm{~m}$ for a wick system of known thickness $(2 \mathrm{~m})$, slope $(10 \%)$, ald slope length $(2 \mathrm{~m})$, and for one combination of porous materials [a bentonite-tuff mix having a 0.02 bentonite ratio by mass overlying 0ttawa sand] subjected to a known addition rate of water (Fig. 12). Using the soil water and tension data collected over time at several positions within the wick layer, we will then be able to field-validate a hydrologic model describing the two-dimensional, unsaturated flow of water through a multilayered system. This data set will then be available to field-validate several hydrologic models, which can subsequently be used for the design of future capillary barriers.

The caissons used in this field experinent are located in experiment clusters (DePoorter 1981) at the Los Alamos Experimental Engineered Test Facility (EETF); the development of this site was sponsored by the DOE National Low-Level Waste Management Program. Each experiment cluster consists of six corrugated metal culverts, $3 \mathrm{~m}$ in diameter and $6 \mathrm{~m}$ deep, placed around a central instrument and access caisson of the same size. In five of the six 

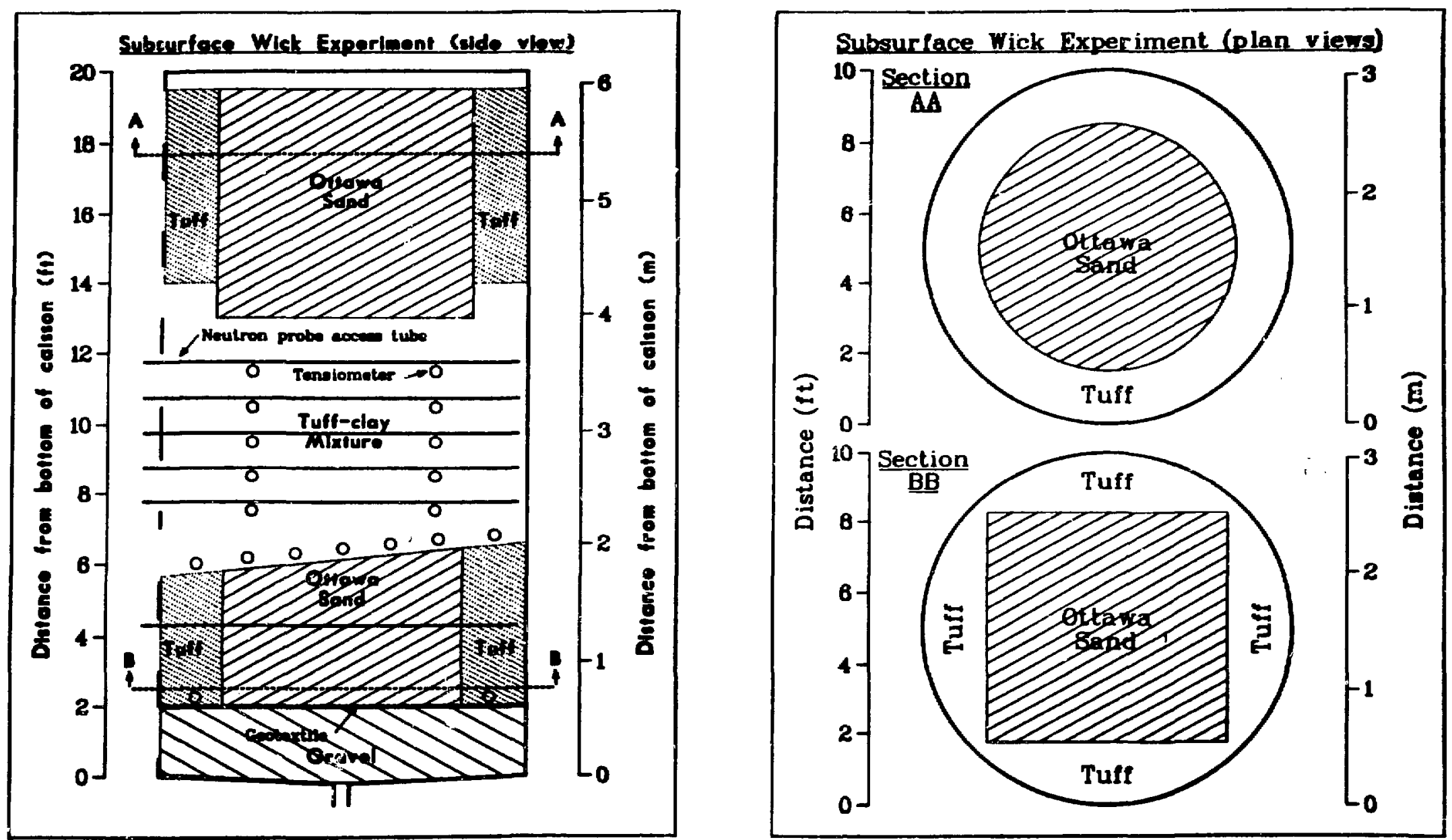
interstitial positions, there are pipes $46 \mathrm{~cm}$ in diameter and $6 \mathrm{~m}$ long. Access ports are situated at $75-\mathrm{cm}$-depth intervals between the central caisson and each of the 11 surrounding caissons (the access ports are shown in detail in Fig. 13).

The Ottawa sand was replaced in the caisson in April 1984 using two metal frames to insure precise geometries of the sand in the experiment. The first metal frame was cmplaced (Fig. 14) to aid in emplacing all but the very top of the sand layer. After this was accomplished and the sand was compacted along with the surrounding tuff (see Fig. 12), the first frame was removed and a second frame, containing a $10 \%$ slope along the ton of the frame, was emplaced. The tuff and sand were added and compacted as before and the second metal frame was then removed.

The $2 \%$ clay/crushed-tuff mixes were made in a cement truck using dried crushed tuff previously screened at the batch plant. The dry tuff (1-2\% water content on a weight, basis) was added to the cement truck (the weight of the tuff was determined by weighing the truck before and after the addition of tuff), and an amount of dr: sodium-saturated bentonite clay was then added to make the $2 \% \mathrm{w} / \mathrm{w}$ mixture. After mixing the dry mix for about an hour, water was added to bring the volumetric water content to about 12-13\%, and this final mixture was mixed for another hour and then added to the caisson. Lifts about 10 to $20 \mathrm{~cm}$ thick were added to Caisson $E$; these were compacted and their density was determined as previously described (Abeele 1984b).

Soil moisture determinations were performed using a Campbell Pacific model 503 neutron moisture gauge. Readings were collected every $30 \mathrm{~cm}$ across the entire width of the caisson on each sampling date. Soil water tension was determined with a Soil Moisture Equipment Corporation model $2100 \mathrm{~F}$ soil moisture probe (with a 3-m-long, flexible plastic tube) modified to determine 


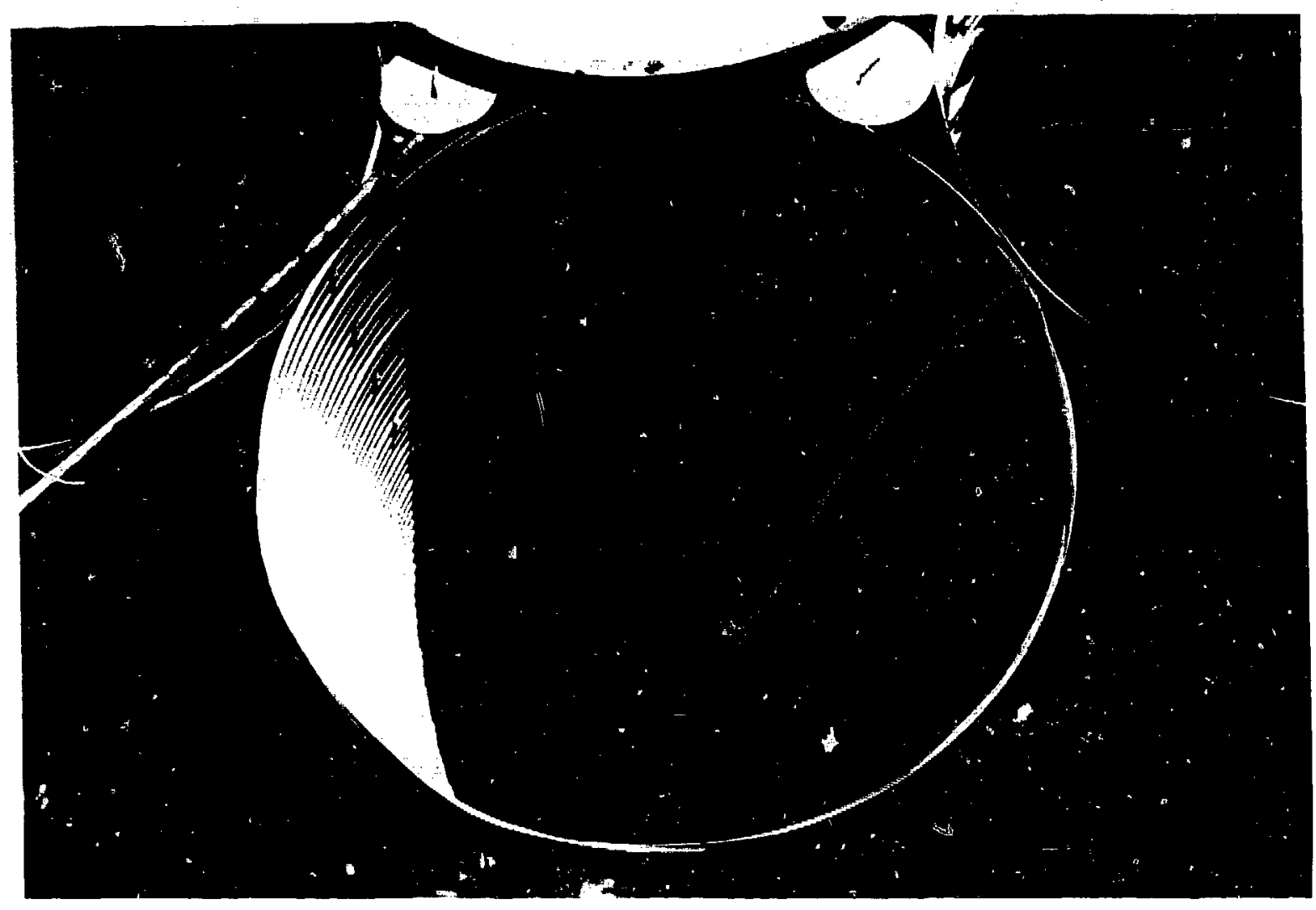

Fig. 13. Access port details in a caisson at the EETF in Los Alamos.

tension using a Soil Measurement Systems tensimeter previously described (Marthaler et al. 1983).

C. Results and Discussion

Over a year's worth of neutron moisture gauge data are presented in Figs. 15 through 19 and summarized in Fig. 20. To be fully understood, this data base needs to be interpreted in conjunction with the water-tension data collected at these same sampling depths (Fig. 21) and at depths located $2 \mathrm{~cm}$ above the interface between the 0ttawa sand and the $2 \%$ bentonite-tuff mixture (Fig. 22).

These soil water content and tension data show that with the increas? of moisture with depths greater than $0.8 \mathrm{~m}$ beneath the mix surface layer, highly 


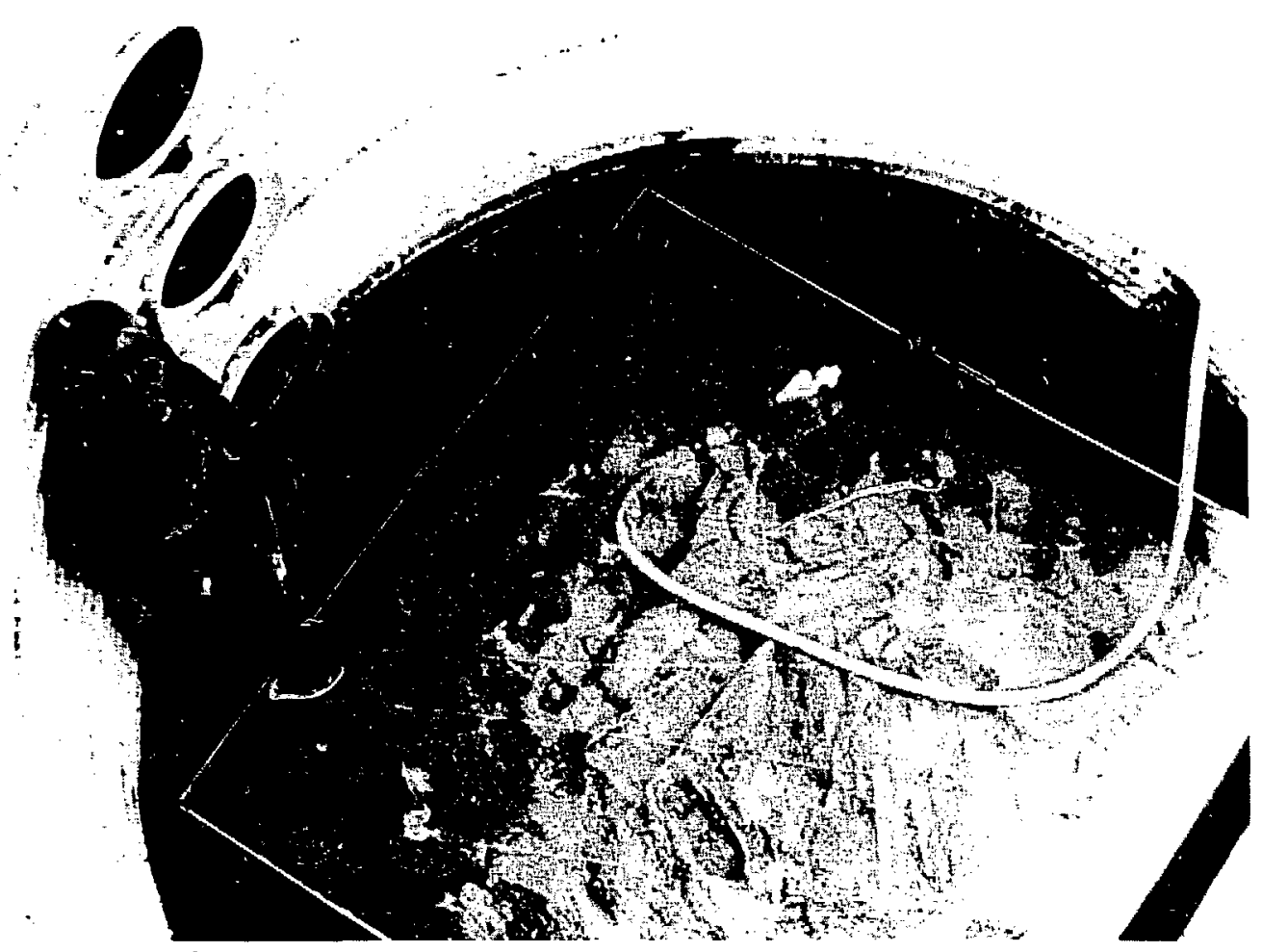

Fig. 14. Emplacing a metal frame in Caisson $E$ to be used to position the Ottawa sand layer (frame was removed after the sand was added and compacted).

unsaturated conditions still prevail. The interesting thing, however, is that for the first time on April 5 (almost a year from the start of the experiment), a discharge of approximately $40 \mathrm{mg}$ of water per second was measured. The fact that the intermediate (thick) layer between the upper surface and the wick interface is unsaturated (negative tension values in Fig. 21) and that, nontheless, a breakthrough or failure of the wick occurred, are sure indications that the wick is behaving the way it is supposed to--somewhere along the interface the wick provided for saturation (positive tension values in Fig. 22) to occur (through unsaturated flow addition of water) with subsequent failure of the system as a result. After saturation - eaches deeper levels, drainage of the system under controlled conditions can occur to permit the application of the instantaneous profile method for unsaturated conductivity computations. 


$$
\text { Caisson "E" 2.5-m Depth }
$$

Distance From Instrument port (m)

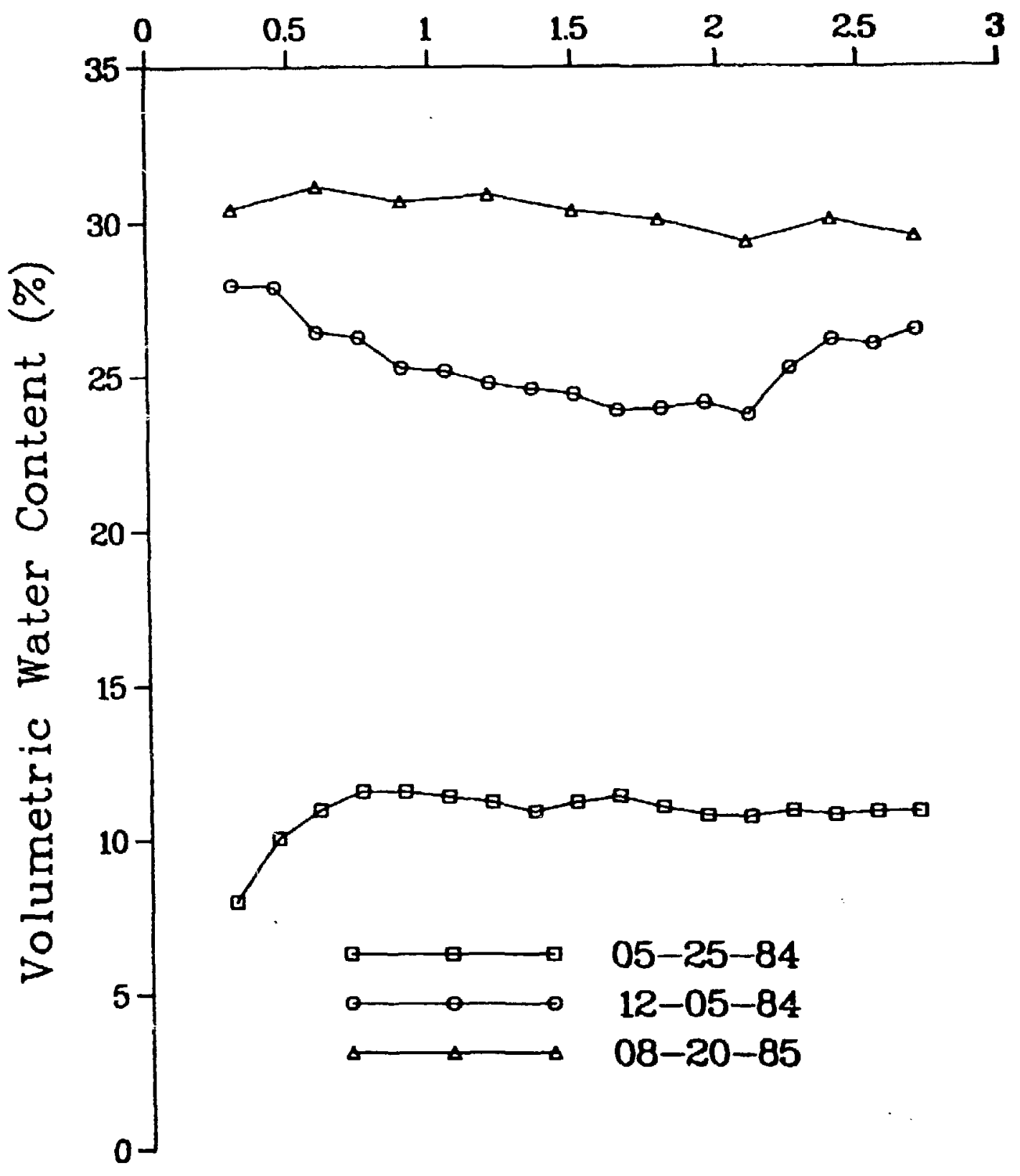

Fig. 15. Soil/water data collected at three sampling dates in Caisson $E$ at the 2.5-cm depth. 


$$
\text { Caisson "E" 2.8-m Depth }
$$

Distance From Instrument Port (m)

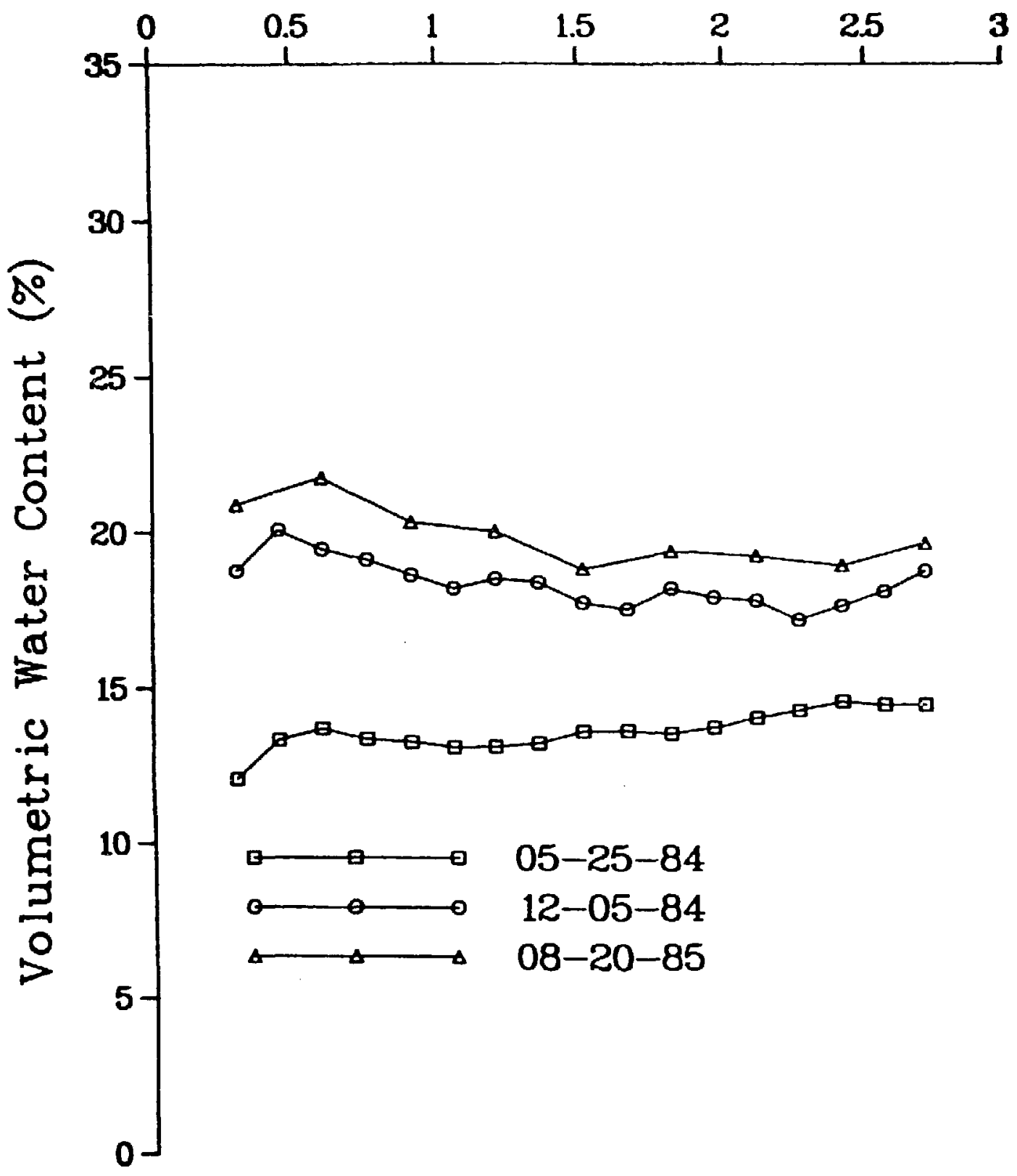

Fig. 16. Soil/water data collected at three sampling dates :Caisson $E$ at the 2.8-m depth. 


$$
\text { Caisson "E" 3.1-m Depth }
$$

Distance From Instrument Port (m)

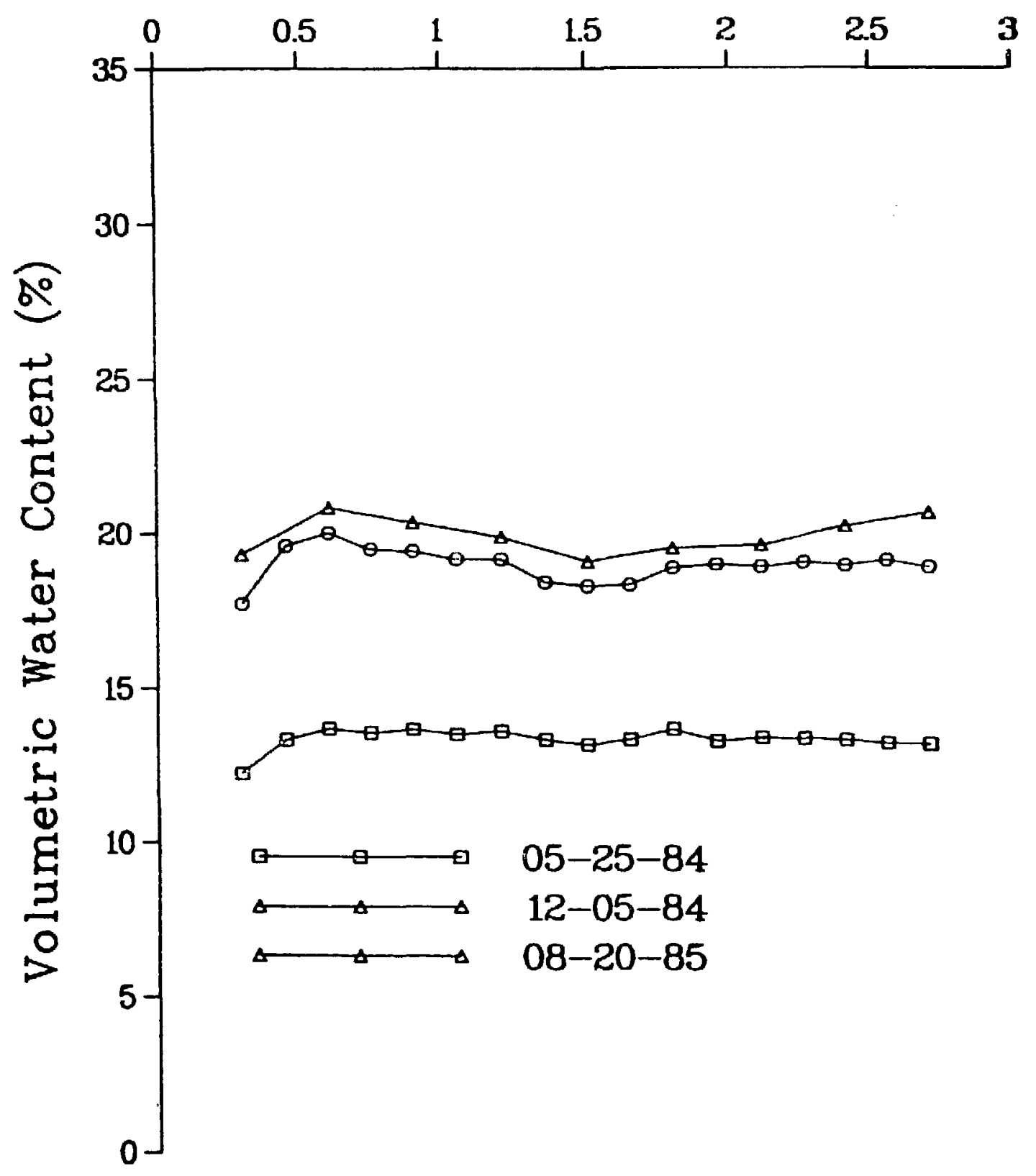

Fig. 17. Soil/water data collected at three sampling dates in Caisson $E$ at the $3.1-m$ depth. 


$$
\text { Caisson "E" 3.4-m Depth }
$$

Dist nce From Instrument Port (m)

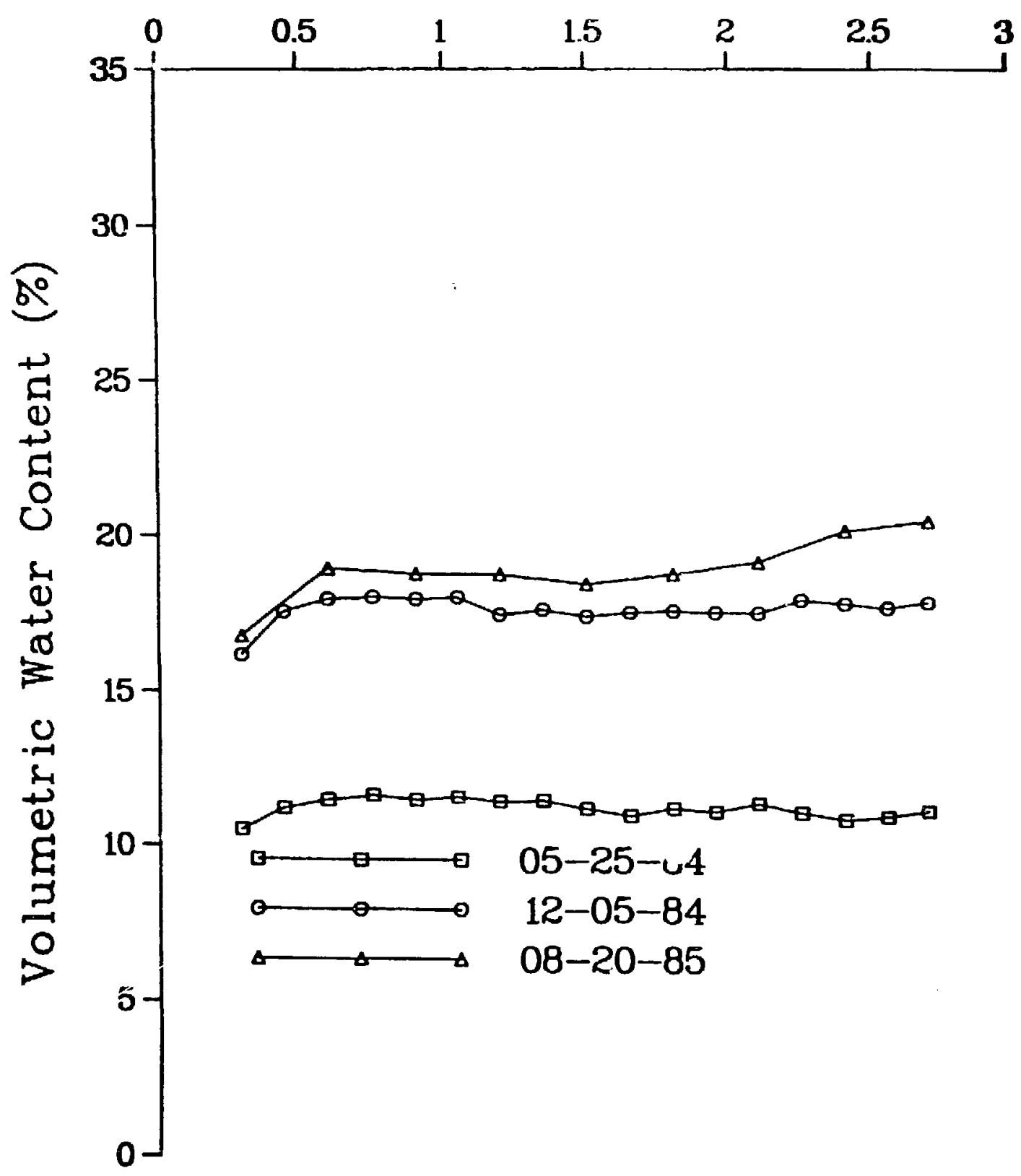

Fig. 18. Soil/water data collected at three sampling dates in Caisson $E$ at the 3.4-m depth. 


$$
\text { Caisson "E" 3.7-m Depth }
$$

Distance From Instrument Port (m)

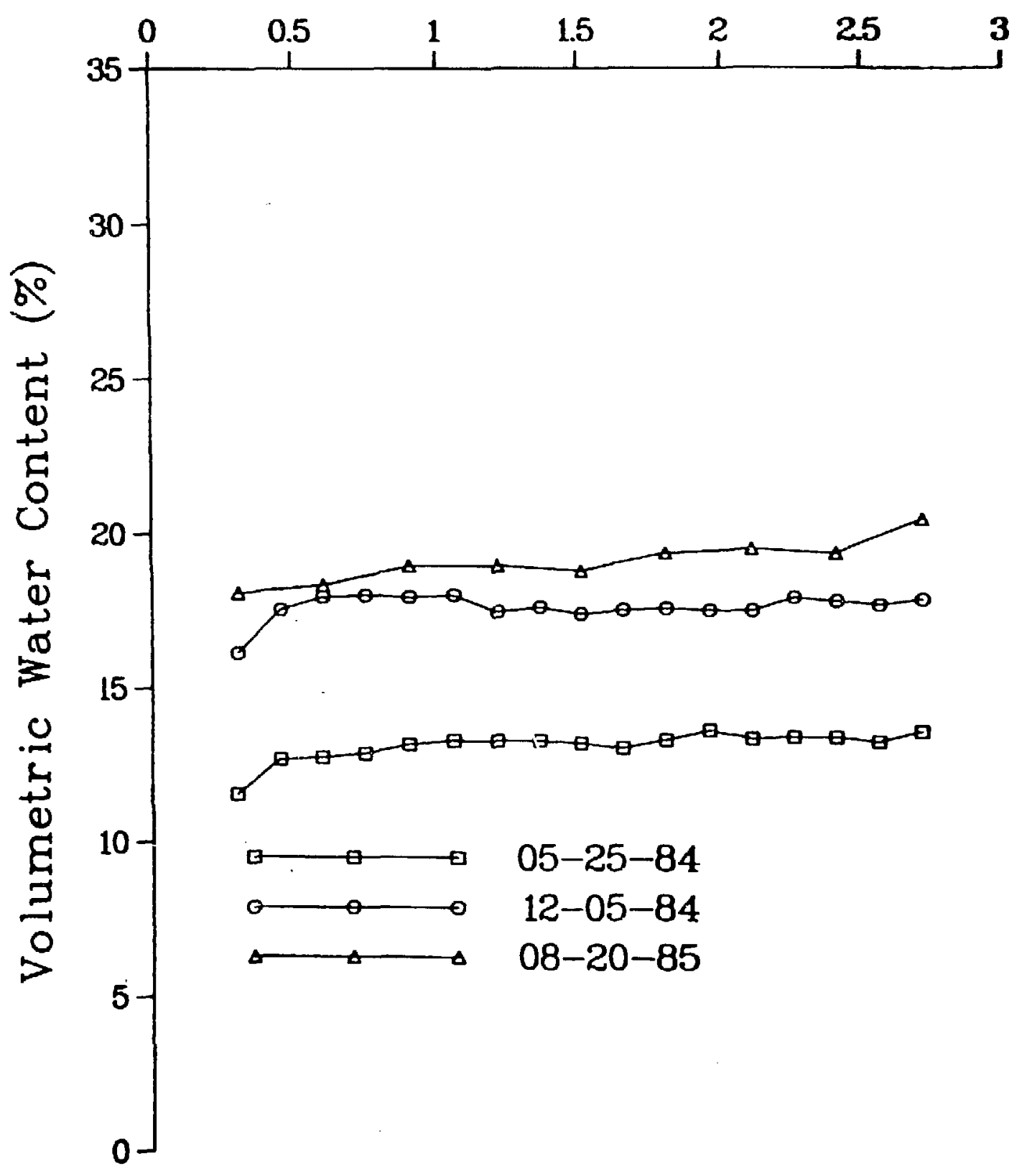

Fig. 19. Soil/water data collected at three sampling dates in Caisson $E$ at the 3.7-m depth. 


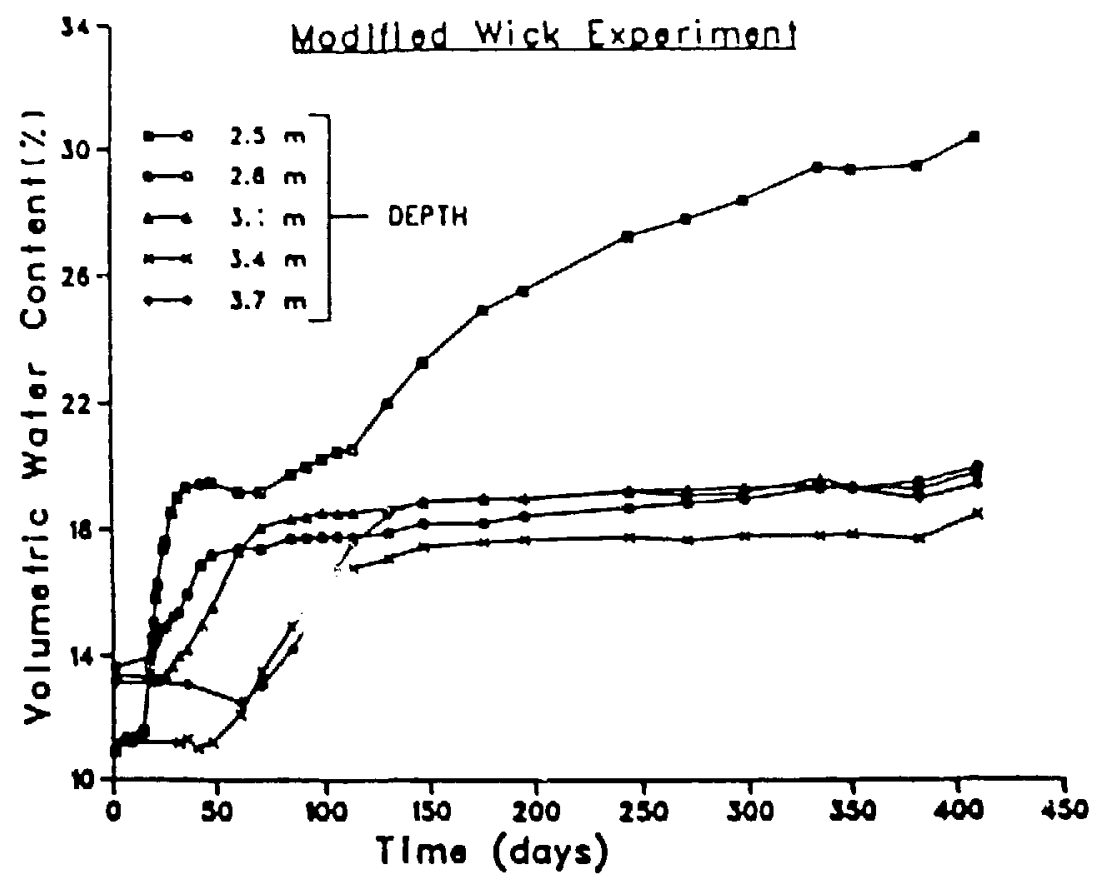

Fig. 20. Distribution of volumetric water content for five sampling depths in the clay-tuff mixture versus time in the envelope wick experiment.

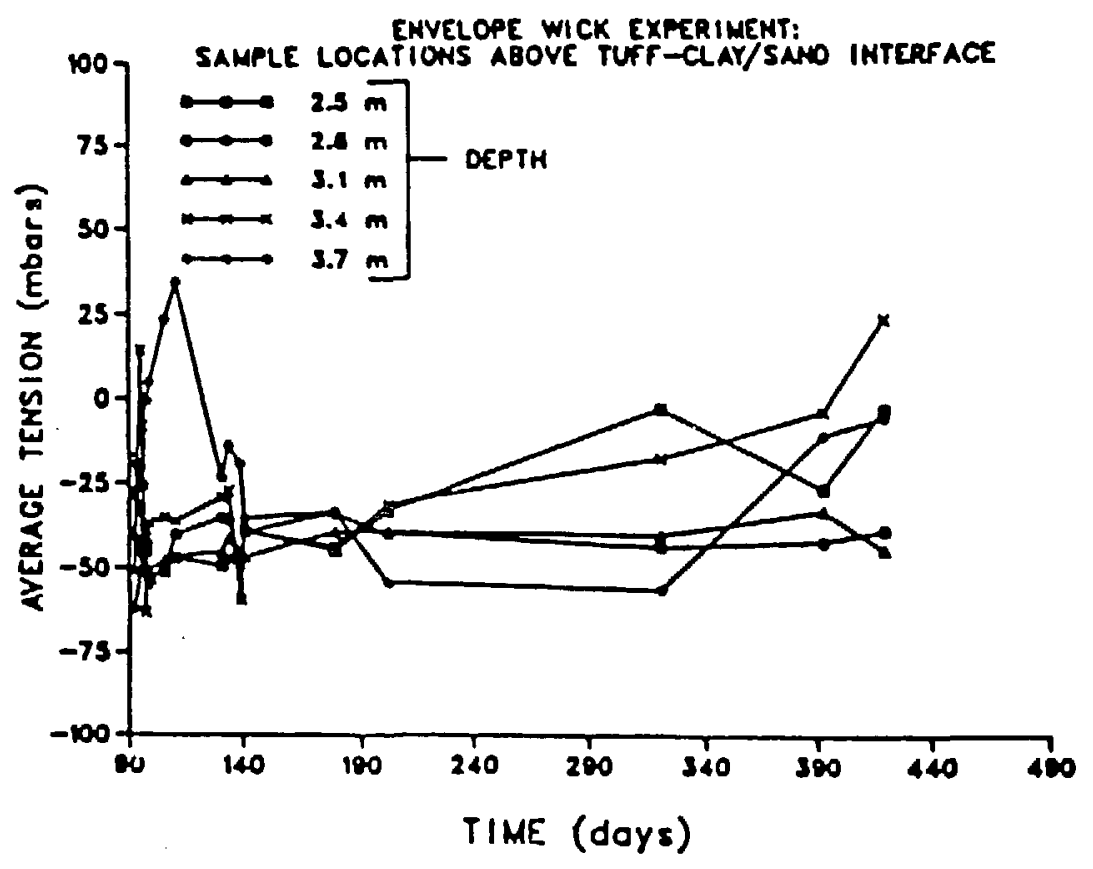

Fig. 21. Soil/water tension data collected above the tuff-clay/sand interface in the envelope wick experiment. 


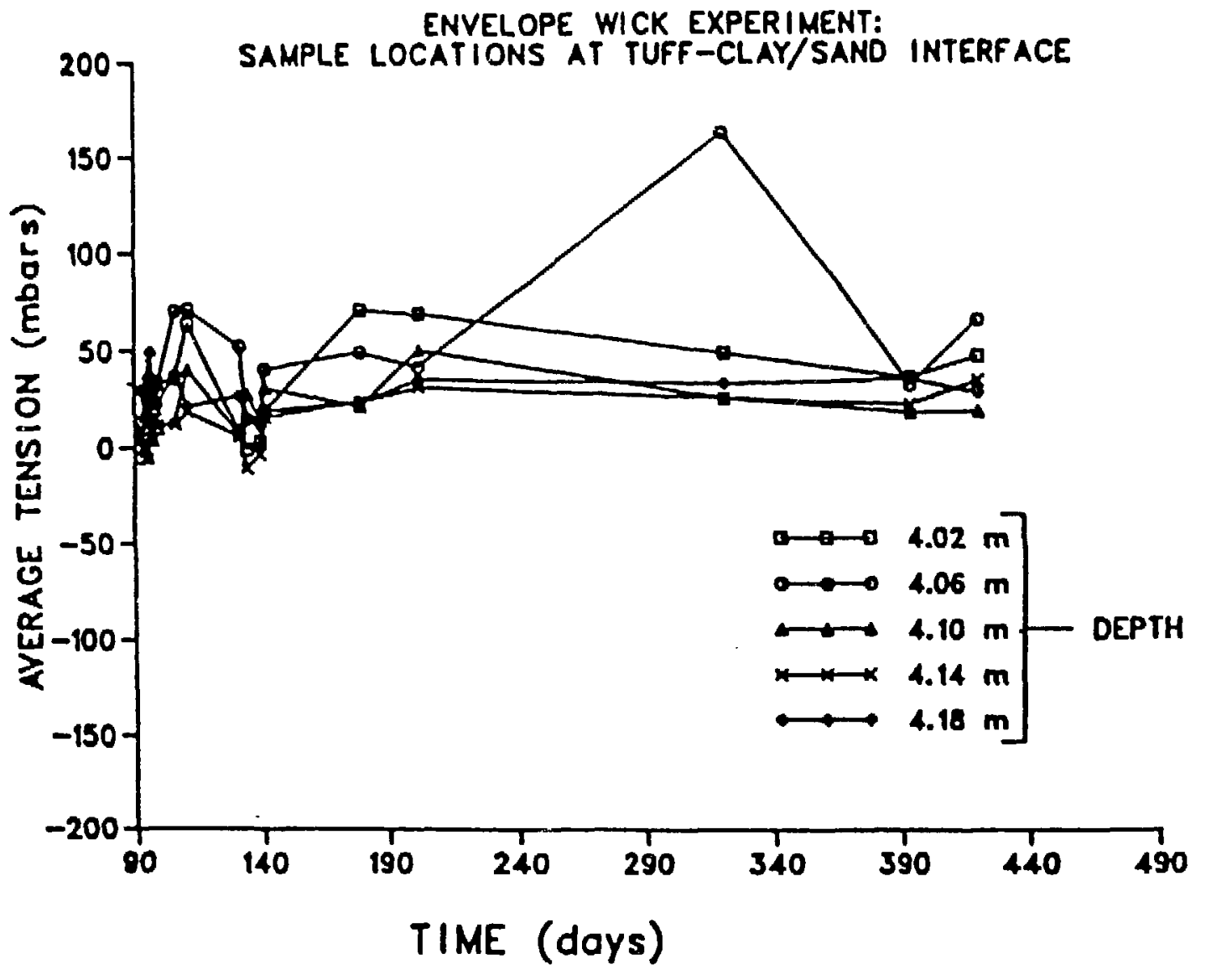

Fig. 22. Soil/water tension data collected at the tuff-clay/sand interface in the envelope wick experiment. 
If we go by the assumption that the discharge from this caisson is regulated by the layer with the lowest hydraulic conductivity, then, since discharge began, the moisture content of the drier layer hovered around $18.4 \%$ moisture by volume and the discharge rate was $4.4 \times 10^{-8} \mathrm{~m}^{3} \mathrm{~s}^{-1}$. This corresponds to a flux of $6.08 \times 10^{-9} \mathrm{~ms}^{-1}$ or a hydraulic conductivity estimated at $3.87 \times 10^{-9} \mathrm{~ms}^{-1}$ for a matric potential gradient tentatively measured to be 1.57 . At a moisture content of $18.4 \%$ by volume, the hydraulic conductivity of pure crushed tuff turned out to be $K=9.3 \times 10^{-3} \theta_{v} 8.21=8.64 \times 10^{-9} \mathrm{~ms}^{-1}$. This shows that at a moisture content by volume of $18.4 \%$, the hydraulic conductivities of pure crushed tuff and of crushed tuff mixed with $2 \%$ bentonite differ by no more than a factor of ten; nowever, the hydraulic conductivity at saturation is about 1000 times greater in pure crushed tuff than in the mix. These data seem to indicate that for the mix there is very little change of permeability as a function of moisture content. It also needs to be pointed out how a big difference in moisture content between the sampling levels results in minor differences in moisture tension (Figs. 21 and 22).

During FY1986, additional data collection activities will continue in this field experiment after saturated flow conditions are met. After this, as the bentonite-tuff mixture dries, our plans are to collect additional tension and soil water-content data for subsequent model verification and validation activities. 


\section{REFERENCES}

Abeele, W. V., "Geotechnical Characteristics of Bentonite/Sandy Silx Mixes for Use in Waste Disposal Sites," Los Alamos National Laboratory report LA-10101-MS (1984a).

Abeele, W. V., "Hydraulic Testing of Crushed Bandelier Tuff," Los Alamos National Labortory report LA-10037-MS (1984b).

Abeele, W. V. and G. L. DePoorter, "Testing of Lateral Water Flow in a Moisture Barrier," Los Alamos National Laboratory report LA-10125-MS (1984). DePoorter, G. L., "The Los Alamos Experimental Engineered Waste Burial Facility: Design Considerations and Preliminary Experimental Plan," in Waste Management ' 81, R. G. Post and M. E. Wacks, Eds. (University of Arizona, 1981), pp. 667-686.

Hakonson, T.E., J.F. Cline, and W. H. Rickard, "Biological Intrusion Barriers for Large Volume Waste Disposal Sites," in Symposium on Low-Level Waste Disposal, Facility Design, Construction, and Operating Practices, M. G. Yalcintas, Ed., NUREG/CP-0028, CONF-820911, Vol. 3, pp. 298-308 (1982a).

Hakonson, T. E., G. C. White, and E. M. Karlen, "Evaluation of Geologic Materials to Limit Biological Intrusion of Low-Level Waste Site Cover," Proc. ANS Topical Meeting, Richland, Washington (1982b).

Hakonson, T. E., "Evaluation of Geologic Materials to Limit Biological Intrusion into Low-Level Radioactive Waste Disposal Sites," Los Alamos National Laboratory report LA-10286-MS (1986).

Lane, L. J., and J. W. Nyhan, "Water and Contaminant Movement: Migration Barriers," Los Alamos National Laboratory report LA-10242-MS (1985).

Marthaler, H. P., W. Vogelsanger, F. Richard, and F. J. Wierenga, "A Pressure Transducer for Field Tensiometers," Soil Sci. Soc. Ami. Journal 47, 624-627 (1983).

Nyhan, J. W., and L. J. Lane, "Use of a State-of-the-Art Model in Generic Designs of Shallow Land Repositories for Low-Level Wastes," in Waste Managmenet '82, R. G. Post, Ed., (University of Arizona, 1982), pp. 235-244.

Nyhan, J.W., W. V. Abeele, E. J. Cokal, and B. A. Perkins, "Technology Development for the Design of Shallow Land Burial Facilities at Arid Sites," in Proceedings of the Sixth Annual Participants Information Meeting, Department of Energy Low-Level Waste Management Program, EG\&G Idaho, Inc. report CONF-8409115:150-171 (Idaho Falls, Idaho, 1984).

Rogers, M. A., "History and Environmental Setting of LASL Near-Surface Land Disposal Facilities for Radioactive Wastes (Areas A, B, C, D, E, F, G, and T)," Los Alamos Scientific Laboratory report LA-6848-MS, Vol. I (1977). 


\section{APPENDIX A}

\section{DESCRIPTION OF VOLUMETRIC WATER CONTENT DATA BASE FOR AREA G}

Sixteen acess tubes were emplaced in the four plots at Area $G$ for the determination of soil water content as a function of time and depth (see Fig. 1 in text). The metal plot borders encompassing the entire study area are actually $23.8 \mathrm{~m}$ long (approximately east-west direction). Proceeding from the east to the west, the plot numbers and treatments are as follows:

(1) Plot 1 (30 cm gravel/70 cm cobble),

(2) Plot 2 (crushed tuff),

(3) Plot 3 (cobble), and

(4) Plot 4 (15 cm gravel/85 cm cobble).

Proceeding from north to south within each of these four plots, access tubes 501, 502, 503, and 504 are located in plot 4; access tubes 505, 506, 507 , and 508 are located in plot 3 ; access tubes $509,510,511$, and 512 are located in plot 2, and access tubes 513,514, 515, and 516 are located in plot 1 .

Access tubes 501 and 513 are located $2.3 \mathrm{~m}$ and $2.1 \mathrm{~m}$, respectively, from the northern plot boundary. Acess tubes 504 and 516 are located $2.3 \mathrm{~m}$ and 2.1 $m$, respectively, from the southern plot boundary. The north-south distances between tubes 501 and 502,502 and 503,503 and 504,505 and 506, 506 and 507, 507 and 508,509 and 510,510 and 511, 511 and 512,513 and 514, 514 and 515,

and 515 and 516 are $2.4 \mathrm{~m}, 2.3 \mathrm{~m}, 2.1 \mathrm{~m}, 2.3 \mathrm{~m}, 2.4 \mathrm{~m}, 2.3 \mathrm{~m}, 2.3 \mathrm{~m}, 2.4 \mathrm{~m}$, $2.3 \mathrm{~m}, 2.0 \mathrm{~m}, 2.5 \mathrm{~m}$, and $2.6 \mathrm{~m}$, respectively. The east-west distances between tubes 501-504 and 505-508, 505-508 and 509-512, and 509-512 and 513-516 are $6.0 \mathrm{~m}, 5.6 \mathrm{~m}$, and $6.2 \mathrm{~m}$, respectively. 
- Type $=$ Cobble only Tube Number $=505 \ldots . . . . . . . .$.

$\begin{array}{lcc}\begin{array}{c}\text { Sampling } \\ \text { Date }\end{array} & \begin{array}{l}\text { Depth From } \\ \text { Surface }(\mathrm{cm})\end{array} & \begin{array}{l}\text { Volumetric } \\ \text { Mo isture } \\ \text { Cuntent }(8)\end{array} \\ \text { 22FEB84 } & 137.16 & 14.8 \\ \text { 04JUN84 } & 137.16 & 14.3 \\ \text { 24JUL84 } & 137.16 & 14.0 \\ \text { 22AUG84 } & 137.16 & 15.8 \\ \text { 12SEP84 } & 137.16 & 14.7 \\ \text { 180CT84 } & 137.16 & 14.1 \\ \text { 07NOV84 } & 137.16 & 14.3 \\ \text { 07NOV84 } & 137.16 & 14.3 \\ \text { 06DEC84 } & 137.16 & 14.1 \\ \text { 04JAN85 } & 137.16 & 20.2 \\ \text { 11FEB85 } & 137.16 & 18.2 \\ \text { 15MAR85 } & 137.16 & 23.4 \\ \text { 20MAR85 } & 137.16 & 24.1 \\ \text { 28MAR85 } & 137.16 & 22.7 \\ \text { 04APR85 } & 137.16 & 24.0 \\ \text { 14MAY85 } & 137.16 & 18.5 \\ \text { 22MAY85 } & 137.16 & 17.3 \\ \text { 30MAY85 } & 137.16 & 17.8 \\ \text { 06JUN85 } & 137.16 & 17.9\end{array}$

\section{Type $=$ Co
Sampling Date}

22FEB 84

04JUN 84

24JUL84

22AUG84

12SEP84

$180 \mathrm{CT} 84$

07 NOV84

07NOV 34

06DEC 84

04JAN85

11 FEB 85

15MAR85

20MAR8 5

28MAR85

04APR8 5

14MAY85

22MAY85

30MAY 85

06JUN85
Depth From

Surface (cm)

137.16

137.16

137.16

137.16

137.16

137.16

137.16

137.16

137.16

137.16

137.16

137.16

137.16

137.16

137.16

137.16

137.16

137.16

137.16
Volumetric

Moisture

Content ( $z$ )

13.4

12.8

12.4

13.7

12.9

12.6

12.6

12.6

12.4

17.4

15.9

20. 1

20.8

19.6

20.3

20.4

25.7

16.0

15.9 


$\begin{array}{lll}\text { 14JUN85 } & 137.16 & 29.5 \\ \text { 16JUL85 } & 137.16 & 15.3 \\ \text { 29JUL85 } & 137.16 & 14.9 \\ \text { 13AUG85 } & 137.16 & 16.3\end{array}$

$\begin{array}{ccc}\begin{array}{c}\text { Sampling } \\ \text { Date }\end{array} & \begin{array}{c}\text { Tube Number }=507 \ldots \\ \text { Depth From } \\ \text { Surface }(\mathrm{cm})\end{array} & \begin{array}{l}\text { Volumetric } \\ \text { Moisture } \\ \text { Content }(8)\end{array} \\ \begin{array}{c}\text { 22FEB84 } \\ \text { 04JUN84 }\end{array} & 137.16 & 11.6 \\ \text { 24JUL84 } & 137.16 & 11.2 \\ \text { 22AUG84 } & 137.16 & 10.4 \\ \text { 12SEP84 } & 137.16 & 11.9 \\ \text { 180CT84 } & 137.16 & 10.9 \\ \text { 07NOV84 } & 137.16 & 10.8 \\ \text { 07NOV84 } & 137.16 & 10.4 \\ \text { 06DEC84 } & 137.16 & 10.4 \\ \text { 04JAN85 } & 137.16 & 18.2 \\ \text { 11FEB85 } & 137.16 & 16.0 \\ \text { 15MAR85 } & 137.16 & 21.3 \\ \text { 20MAR85 } & 137.16 & 21.5 \\ \text { 28MAR85 } & 137.16 & 21.0 \\ \text { 04APR85 } & 137.16 & 22.2 \\ \text { 14MAY85 } & 137.16 & 17.1 \\ \text { 22MAY85 } & 137.16 & 26.3 \\ \text { 30MAY85 } & 137.16 & 16.9 \\ \text { 14JUN85 } & 137.16 & 30.7 \\ \text { 16JUL85 } & 137.16 & 15.6 \\ \text { 29JUL85 } & 137.16 & 15.4 \\ \text { 13AUG85 } & 137.16 & 16.2 \\ & & \end{array}$

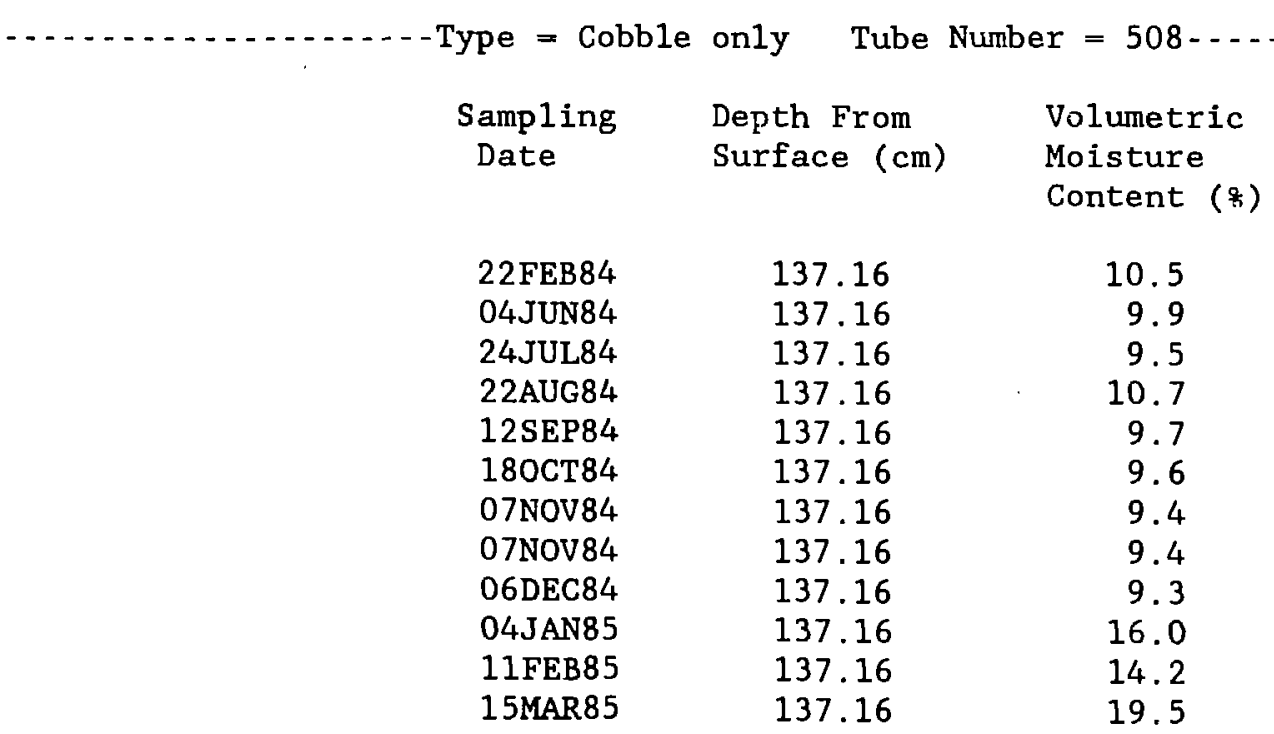




$\begin{array}{lll}\text { 2OMAR85 } & 137.16 & 20.2 \\ \text { 28MAR85 } & 137.16 & 19.4 \\ \text { 04APR85 } & 137.16 & 20.6 \\ \text { 14MAY85 } & 137.16 & 19.3 \\ \text { 22MAY85 } & 137.16 & 35.0 \\ \text { 30MAY85 } & 137.16 & 15.3 \\ \text { 06JUN85 } & 137.16 & 21.1 \\ \text { 14JUN85 } & 137.16 & 19.2 \\ \text { 16JUL85 } & 137.16 & 14.4 \\ \text { 29JUL85 } & 137.16 & 14.5 \\ \text { 13AUG85 } & 137.16 & 14.3\end{array}$

Type

$$
\begin{gathered}
\text { Sampling } \\
\text { Date }
\end{gathered}
$$

22FEB 84

04JUN84

24JUL84

22AUG84

12 SEP 84

180CT84

07 NOV84

07NOV84

06DEC 84

04JAN85

11 FEB 85

15MAR 8

20MAR 85

28MAR8 5

04APR 85

14MAY85

22MAY85

30 MAY85

06JUN85

14JUN85

16JUL85

29JUL8 5

13 AUG 85
Depth From
Surface $(\mathrm{cm})$

137.16

137.16

137.16

137.16

137.16

137.16

137.16

137.16

137.16

137.16

137.16

137.16

137.16

137.16

137.16

137.16

137.16

137.16

137.16

137.16

137.16

137.16

137.16

Tube Number $=51.3$

20.2

19.4

20.6

19.3

35.0

15.3

21.1

19.2

14.4

14.5

14.3
Volumetric

Moisture

Content (z)

12.4

11.9

11.3

12.9

11.7

11.5

11.1

11.1

11.2

17.5

16.4

21.2

20.0

19.3

20.4

17.0

16.0

16.0

15.4

30.0

15.0

14.6

14.8

- Type $=$

Sampling
Date

22FEB 84

04JUNN84

24JUL84

22AUG84

12SEP84
137.16

137.16

137.16

137.16

137.16

Tube Number $=515$

Volumetric

Moisture

Content ( $z)$

10.7

10.7

9.9

11.0

10.5 


$\begin{array}{lll}\text { 180CT84 } & 137.16 & 10.2 \\ \text { 07NOV84 } & 137.16 & 10.4 \\ \text { 07NOV84 } & 137.16 & 10.4 \\ \text { 06DEC84 } & 137.16 & 10.3 \\ \text { 04JAN85 } & 137.16 & 17.7 \\ \text { 11FEB85 } & 137.16 & 15.0 \\ \text { 15MAR85 } & 137.16 & 21.4 \\ \text { 20MAR85 } & 137.16 & 20.3 \\ \text { 28MAR85 } & 137.16 & 19.6 \\ \text { 04APR85 } & 137.16 & 21.0 \\ \text { 14MAY85 } & 137.16 & 21.1 \\ \text { 22MAY85 } & 137.16 & 22.3 \\ \text { 30MAY85 } & 137.16 & 15.8 \\ \text { 06JUN85 } & 137.16 & 15.5 \\ \text { 14JUN85 } & 137.16 & 15.2 \\ \text { 16JUL85 } & 137.16 & 14.5 \\ \text { 29JUL85 } & 137.16 & 14.4 \\ \text { 13AUG85 } & 137.16 & 14.1\end{array}$

Cobble-grave1 75-25 Tube Number $=516 \ldots \ldots \ldots$

$\begin{array}{cll}\text { Sampling } & \text { Depth From } & \text { Volumetric } \\ \text { Date } & \text { Surface (cm) } & \begin{array}{l}\text { Moisture } \\ \text { Content (8) }\end{array}\end{array}$

$\begin{array}{lrr}\text { 22FEB84 } & 137.16 & 10.9 \\ \text { 04JUN84 } & 137.16 & 10.5 \\ \text { 24JUL84 } & 137.16 & 9.8 \\ \text { 22AUG84 } & 137.16 & 11.1 \\ \text { 12SEP84 } & 137.16 & 10.5 \\ \text { 180CT84 } & 137.16 & 10.2 \\ \text { 07NOV84 } & 137.16 & 10.1 \\ \text { 07NOV84 } & 137.16 & 10.1 \\ \text { 06DEC84 } & 137.16 & 10.0 \\ \text { 04JAN85 } & 137.16 & 16.0 \\ \text { 11FEB85 } & 137.16 & 14.9 \\ \text { 15MAR85 } & 137.16 & 19.2 \\ \text { 2OMAR85 } & 137.16 & 19.5 \\ \text { 28MAR85 } & 137.16 & 18.3 \\ \text { 04APR85 } & 137.16 & 19.4 \\ \text { 14MAY85 } & 137.16 & 14.9 \\ \text { 22MAY85 } & 137.16 & 28.9 \\ \text { 3OMAY85 } & 137.16 & 14.8 \\ \text { 06JUN85 } & 137.16 & 14.0 \\ \text { 14JUN85 } & 137.16 & 14.7 \\ \text { 2 JUL85 } & 137.16 & 13.9 \\ \text { 29JUL85 } & 137.16 & 13.5 \\ \text { 13AUG85 } & 137.16 & 13.4\end{array}$

Tube Number $=501 \ldots \ldots \ldots$

Sampling Depth From Volumetric 


$\begin{array}{lcc}\text { Date } & \text { Surface (cm) } & \begin{array}{l}\text { Moisture } \\ \text { Content }(8)\end{array} \\ \text { 22FEB84 } & 137.16 & 15.8 \\ \text { 04JUN84 } & 137.16 & 15.3 \\ \text { 24JUL84 } & 137.16 & 14.9 \\ \text { 22AUG84 } & 137.16 & 16.7 \\ \text { 12SEP84 } & 137.16 & 15.1 \\ \text { 180CT84 } & 137.16 & 14.9 \\ \text { 07NOV84 } & 137.16 & 15.1 \\ \text { 07NOV84 } & 137.16 & 15.1 \\ \text { 06DEC84 } & 137.16 & 15.4 \\ \text { 04JAN85 } & 137.16 & 19.9 \\ \text { 11FEB85 } & 137.16 & 17.2 \\ \text { 15MAR85 } & 137.16 & 23.0 \\ \text { 20MAR85 } & 137.16 & 23.1 \\ \text { 28MAR85 } & 137.16 & 22.5 \\ \text { 04APR85 } & 137.16 & 23.4 \\ \text { 14MAY85 } & 137.16 & 17.2 \\ \text { 22MAY85 } & 137.16 & 19.8 \\ \text { 30MAY85 } & 137.16 & 17.2 \\ \text { 06JUN85 } & 137.16 & 18.3 \\ \text { 14JUN85 } & 137.16 & 17.3 \\ \text { 16JUL85 } & 137.16 & 16.5 \\ \text { 29JUL85 } & 137.16 & 16.3 \\ \text { 13AUG85 } & 137.16 & 16.6\end{array}$

Tube Number $=502 \ldots \ldots \ldots$

$\begin{array}{lcc}\begin{array}{l}\text { Sampling } \\ \text { Date }\end{array} & \begin{array}{l}\text { Depth From } \\ \text { Surface (cm) }\end{array} & \begin{array}{l}\text { Volumetric } \\ \text { Moisture } \\ \text { Content (8) }\end{array} \\ \text { 22FEB84 } & 137.16 & 13.9 \\ \text { 04JUN84 } & 137.16 & 13.3 \\ \text { 24JUL84 } & 137.16 & 12.9 \\ \text { 22AUG84 } & 137.16 & 14.4 \\ \text { 12SEP84 } & 137.16 & 13.6 \\ \text { 180CT84 } & 137.16 & 12.9 \\ \text { 07NOV84 } & 137.16 & 12.7 \\ \text { 07NOV84 } & 137.16 & 12.7 \\ \text { 06DEC84 } & 137.16 & 12.6 \\ \text { 04JAN85 } & 137.16 & 17.9 \\ \text { 11FEB85 } & 137.16 & 16.4 \\ \text { 15MAR85 } & 137.16 & 22.0 \\ \text { 20MAR85 } & 137.16 & 22.2 \\ \text { 28MAR85 } & 137.16 & 21.5 \\ \text { 04APR85 } & 137.16 & 22.3 \\ \text { 14MAY85 } & 137.16 & 17.1 \\ \text { 22MAY85 } & 137.16 & 16.3 \\ \text { 30MAY85 } & 137.16 & 16.9 \\ \text { 06JUN85 } & 137.16 & 17.0 \\ \text { 14JUN85 } & 137.16 & 16.8\end{array}$




$\begin{array}{lll}\text { 16JUL85 } & 137.16 & 16.0 \\ \text { 29JUL85 } & 137.16 & 15.7 \\ \text { 13AUG85 } & 137.16 & 15.6\end{array}$

- Type $=$ Cobble-gravel $85-15$ Tube Number $=503 \ldots \ldots \ldots \ldots$

$\begin{array}{cll}\text { Sampling } & \text { Depth From } & \text { Volumetric } \\ \text { Date } & \text { Surface }(\mathrm{cm}) & \begin{array}{l}\text { Moisture } \\ \text { Content }(\mathrm{z})\end{array}\end{array}$

$\begin{array}{llr}\text { 22FEB84 } & 137.16 & 13.2 \\ \text { 04JUN84 } & 137.16 & 12.9 \\ \text { 24JUL84 } & 137.16 & 12.4 \\ \text { 22AUG84 } & 137.16 & 13.8 \\ \text { 12SEP84 } & 137.16 & 12.6 \\ \text { 180CT84 } & 137.16 & 12.8 \\ \text { 07NOV84 } & 137.16 & 12.4 \\ \text { 07NOV84 } & 137.16 & 12.4 \\ \text { 06DEC84 } & 137.16 & 12.5 \\ \text { 04JAN85 } & 137.16 & 16.1 \\ \text { 11FEB85 } & 137.16 & 14.9 \\ \text { 15MAR85 } & 137.16 & 19.2 \\ \text { 20MAR85 } & 137.16 & 20.6 \\ \text { 20MAR85 } & 137.16 & 8.4 \\ \text { 28MAR85 } & 137.16 & 20.0 \\ \text { 04APR85 } & 137.16 & 21.6 \\ \text { 14MAY85 } & 137.16 & 21.6 \\ \text { 22MAY85 } & 137.16 & 17.4 \\ \text { 30MAY85 } & 137.16 & 16.3 \\ \text { 06JUN85 } & 137.16 & 16.2 \\ \text { 14JUN85 } & 137.16 & 16.0 \\ \text { 16JUL85 } & 137.16 & 15.4 \\ \text { 29JUL85 } & 137.16 & 15.2 \\ \text { 13AUG85 } & 137.16 & 14.6\end{array}$

- Type $=$ Cobble-grave1 85-15 Tube Number $=504 \ldots \ldots$

\begin{tabular}{|c|c|c|}
\hline $\begin{array}{l}\text { Sampling } \\
\text { Date }\end{array}$ & $\begin{array}{l}\text { Depth From } \\
\text { Surface (cm) }\end{array}$ & $\begin{array}{l}\text { Volumetric } \\
\text { Moisture } \\
\text { Content ( })\end{array}$ \\
\hline
\end{tabular}

$\begin{array}{lll}\text { 22FEB84 } & 137.16 & 6.5 \\ \text { 04JUN84 } & 137.16 & 5.9 \\ \text { 24JUL84 } & 137.16 & 5.1 \\ \text { 22AUG84 } & 137.16 & 5.9 \\ \text { 12SEP84 } & 137.16 & 5.6 \\ \text { 180CT84 } & 137.16 & 5.6 \\ \text { 07NOV84 } & 137.16 & 5.6 \\ \text { 07NOV84 } & 137.16 & 5.6 \\ \text { 06DEC84 } & 137.16 & 5.5 \\ \text { 04JAN85 } & 137.16 & 6.7 \\ \text { 11FEB85 } & 137.16 & 6.4\end{array}$




$\begin{array}{lrr}\text { 15MAR85 } & 137.16 & 8.5 \\ \text { 28MAR85 } & 137.16 & 8.1 \\ \text { 04APR85 } & 137.16 & 8.6 \\ \text { 14MAY85 } & 137.16 & 6.3 \\ \text { 22MAY85 } & 137.16 & 23.4 \\ \text { 30MAY85 } & 137.16 & 6.6 \\ \text { 06JUN85 } & 137.16 & 6.5 \\ \text { 14JUN85 } & 137.16 & 6.3 \\ \text { 16JUL85 } & 137.16 & 6.3 \\ \text { 29JUL85 } & 137.16 & 5.9 \\ \text { 13AUG85 } & 137.16 & 6.1\end{array}$

- Type $=$ Crushed tuff Tube Number $=509 \ldots \ldots . . . . . . .$.

Sampling

Date

22FEB84

22FEB84

22FEB84

22FEB 84

04JUN84

04JUN84

04JUN84

04JUN84

24JUL84

24JUL84

24JUL84

24JUL84

22AUG84

22AUG84

22AUG84

22AUG84

$12 S E P 84$

$12 S E P 84$

12SEP84

$12 \mathrm{SEP} 84$

180CT 84

180CT 84

$180 \mathrm{CT} 84$

180CT84

07NOV84

07NOV84

07NOV84

07NOV84

07NOV84

07NOV84

07NOV 84

07NOV84

06DEC 84

06DEC84

06DEC84

\section{Depth From}

Surface $(\mathrm{cm})$

91.44

106.68

121.92

137.16

91.44

106.68

121.92

137.16

91.44

106.68

121.92

137.16

91.44

106.68

121.92

137.16

91.44

106.68

121.92

137.16

91.44

106.68

121.92

137.16

91.44

91.44

106.68

106.68

121.92

121.92

137.16

137.16

91.44

106.68

121.92
Volumetric

Moisture

Content ( 8 )

7.9

4.6

7.1

11.2

3.8

5.6

6.8

10.6

2.9

4.9

7.6

9.7

2.4

3.2

6.5

11.1

1.9

3. 3

6.7

10.5

2.9

4.1

7.5

10.2

9.0

9.0

3.9

3.9

6.4

6.4

10.2

10.2

8.9

5.2

5.8 


\begin{tabular}{|c|c|c|}
\hline 06DEC84 & 137.16 & 9.8 \\
\hline 04JAN85 & 91.44 & 16.7 \\
\hline 04JAN85 & 106.68 & 13.3 \\
\hline 04JAN85 & 121.92 & 6.7 \\
\hline 04JAN85 & 137.16 & 9.9 \\
\hline 11FEB85 & 91.44 & 15.6 \\
\hline 11FEB85 & 106.68 & 12.1 \\
\hline 11FEB85 & 121.92 & 10.5 \\
\hline 11FEB85 & 137.16 & 10.5 \\
\hline 15MAR85 & $91.4: 4$ & 21.9 \\
\hline 15MAR85 & 106.68 & 17.1 \\
\hline 15MAR85 & 121.92 & 12.8 \\
\hline I5MAR85 & 137.16 & 12.7 \\
\hline 20MAR85 & 91.44 & 20.1 \\
\hline 20MAR8 5 & 106.68 & 19.3 \\
\hline 20MAR85 & 121.92 & 15.8 \\
\hline 20MAR8 5 & 137.16 & 13.1 \\
\hline 28MAR85 & 91.44 & 17.9 \\
\hline 28MAR8 5 & 106.68 & 18.8 \\
\hline 28MAR85 & 121.92 & 17.1 \\
\hline 28MAR8 5 & 137.16 & 15.2 \\
\hline 04APR85 & 91.44 & 19.7 \\
\hline 04APR85 & 106.68 & 20.4 \\
\hline 04APR85 & 121.92 & 18.2 \\
\hline 04APR85 & 137.16 & 18.1 \\
\hline 14MAY85 & 91.44 & 12.8 \\
\hline 14MAY85 & 106.68 & 15.0 \\
\hline 14MAY85 & 121.92 & 14.6 \\
\hline 14MAY85 & 137.16 & 21.4 \\
\hline 22MAY85 & 91.44 & 13.1 \\
\hline 22MAY85 & 106.68 & 14.9 \\
\hline 22MAY85 & 121.92 & 14.5 \\
\hline 22MAY85 & 137.16 & 17.4 \\
\hline 30MAY85 & $\$ 1.44$ & 12.0 \\
\hline 30MA 85 & 106.68 & 14.4 \\
\hline 30MAY85 & 121.92 & 13.7 \\
\hline 30MAY85 & 137.16 & 17.5 \\
\hline 06JUN85 & 91.44 & 11.2 \\
\hline 06JUN85 & 106.68 & 13.6 \\
\hline 06JUN85 & 121.92 & 13.4 \\
\hline 06JUN85 & 137.16 & 17.1 \\
\hline 14JUN8 5 & 91.44 & 9.9 \\
\hline 14JUN8 5 & 106.68 & 12.4 \\
\hline 14JUN85 & 121.92 & 12.8 \\
\hline 14JUN8 5 & 137.16 & 17.2 \\
\hline 16JUL85 & 91.44 & 5.0 \\
\hline 16JUL85 & 106.68 & 8.3 \\
\hline 16JUL85 & 121.92 & 10.3 \\
\hline 16JUL85 & 137.16 & 16.1 \\
\hline 29JUL85 & 91.44 & 3.9 \\
\hline 29JUL85 & 106.68 & 7.3 \\
\hline 29JUL85 & 121.92 & 9.5 \\
\hline 29JUL85 & 137.16 & 15.1 \\
\hline 13AUG85 & 91.44 & 11.2 \\
\hline
\end{tabular}




$\begin{array}{rrr}\text { 13AUG8: } & 106.68 & 7.9 \\ \text { 13AUG85 } & 121.92 & 9.0 \\ 13 \text { AUG85 } & 137.16 & 14.5\end{array}$

- Type $=$ Crushed tuff Tube Number $=510 \ldots . . . . . . . .$.

Sampling

Date

22 FEB 84

22FEB84

$22 F E B 84$

22 FEB 84

04JUN84

04JUN84

04 JUN84

04JUN84

24JUL84

24JUL84

24 JUL84

24JUL84

22AUG84

22AUG 84

22AUG84

22AUG84

12SEP84

12SEP 84

12SEP84

12SEP84

180CT 84

180CT 84

180CT 84

180CT 84

07 NOV 84

07NOV84

07NOV84

07NOV84

07NOV84

07NOV84

07NOV84

07NOV84

06DEC 84

06DEC84

06DEC84

06DEC84

04JAN85

04JAN8 5

04JAN85

04JAN85

11FEB85

11FEB85

11 FEB 85

\section{Depth From}

Surface (cm)

91.44

106.68

121.92

137.16

91.44

106.68

121.92

137.16

91.44

106.68

121.92

137.16

91.44

106.68

121.32

137.16

91.44

106.68

121.92

137.16

91.44

106.68

121.92

137.16

91.44

91.44

106.68

106.68

121.92

121.92

137.16

137.16

91.44

106.68

121.92

137.16

91.44

106.68

121.92

137.16

91.44

106.68

121.92
Volumetric

Moisture

Content ( 8 )

9.1

3.4

4.3

11.4

3.1

3.3

3.8

10.5

2.0

1.9

3.6

9.5

2.1

2.0

2.7

10.8

1.8

1.8

3.1

9.7

3.1

2.4

4.4

9.7

10.8

10.8

3.0

3.0

3.4

3.4

10.1

10.1

9.3

4.7

3.1

10.1

16.5

12.6

3.6

10.2

15.0

11.9

9.0 


\begin{tabular}{|c|c|c|}
\hline 11FEB85 & 137.16 & 10.3 \\
\hline 15MAR85 & 91.44 & 22.5 \\
\hline 15MAR85 & 106.68 & 16.5 \\
\hline 15MAR85 & 121.92 & 12.0 \\
\hline 15MAR.35 & 137.16 & 12.0 \\
\hline 20MAR85 & 91.44 & 20.6 \\
\hline 20MAR85 & 106.68 & 18.5 \\
\hline 7.0MAR85 & 121.92 & 14.6 \\
\hline 20MAR85 & 137.16 & 12.9 \\
\hline 28MAR85 & 91.44 & 19.1 \\
\hline 28MAR85 & 106.68 & 18.1 \\
\hline 28MAR85 & 121.92 & 16.0 \\
\hline 28MAR85 & 137.16 & 14.6 \\
\hline 04APR8 5 & 91.44 & 20.9 \\
\hline 04APR85 & 106.68 & 19.7 \\
\hline 04APR8 5 & 121.92 & 17.1 \\
\hline 04APR85 & 137.16 & 17.4 \\
\hline 14MAY85 & 91.44 & 14.3 \\
\hline 14MAY:85 & 106.68 & 14.7 \\
\hline 14MAY85 & 121.92 & 13.6 \\
\hline 14MAY85 & 137.16 & 26.4 \\
\hline 22MAY85 & 91.44 & 18.2 \\
\hline 22MAY85 & 106.68 & 17.2 \\
\hline 22MAY85 & 121.92 & 21.5 \\
\hline 22MAY85 & 137.16 & 17.3 \\
\hline 30MAY85 & 91.44 & 12.2 \\
\hline 30MAY85 & 106.68 & 13.7 \\
\hline 30MAY85 & 121.92 & 13.4 \\
\hline 30MAY85 & 137.16 & 17.8 \\
\hline 06JUN85 & 91.44 & 11.3 \\
\hline 06JUN85 & 106.68 & 12.8 \\
\hline 06JUN85 & 121.92 & 13.2 \\
\hline 06JUN85 & 137.16 & 0.4 \\
\hline 14JUN85 & 91.44 & 7.0 \\
\hline 14JUN85 & 106.68 & 11.5 \\
\hline 14JUN85 & 121.92 & 12.3 \\
\hline 14JUN85 & 137.16 & 16.9 \\
\hline 16JUL85 & 91.44 & 2.6 \\
\hline 16JUL85 & 106.68 & 4.7 \\
\hline 16JUL85 & 121.92 & 9.8 \\
\hline 16JUL85 & 137.16 & 15.3 \\
\hline 29JUL85 & 91.44 & 2.5 \\
\hline 29JUL85 & 106.68 & 3.5 \\
\hline 29JUL85 & 121.92 & 7.6 \\
\hline 29JUL85 & 137.16 & 15.1 \\
\hline 13AUG85 & 91.44 & 11.6 \\
\hline 13AUG85 & 106.68 & 3.1 \\
\hline 13AUG85 & 121.92 & 5.4 \\
\hline 13AUG85 & 137.16 & 14.2 \\
\hline
\end{tabular}

- Type $=$ Crushed tuff Tube Number $=511 \ldots \ldots \ldots \ldots$ Sampling Depth From Volumetric 
Date

22FEB 84

$22 \mathrm{FEB} 84$

22FEB84

22FEB84

04JUN84

04JUN84

04JUN84

04JUN84

24JUL84

24JUL84

24JUL84

24JUL84

22AUG84

22AUG84

22AUG84

22AUG84

12SEP84

12SEP84

12SEP84

12SEP84

180CT'84

$180 \mathrm{CT} 84$

$180 \mathrm{CT} 84$

$180 \mathrm{CT} 84$

07NOV84

07NOV84

07NOV 84

07NOV84

07NOV84

07NOV84

07NOV84

07NOV84

06DEC 84

06DEC84

06DEC84

06DEC84

04JAN85

04JAN85

04JAN8 5

04JAN8 5

11FEB85

11FEB85

11 FEB 85

11FEB85

15MAR85

ISMAR85

15MAR8 5

15MAR 85

20MAR8 5

20MAR 85

20MAR85

Surface (cm) Moisture

Content ( 8 )

91.44

106.68

121.92

137.16

91.44

106.68

121.92

137.16

91.44

106.68

121.92

137.16

91.44

106.68

121.92

137.16

91.44

106.68

121.92

137.16

91.44

106.68

121.92

137.16

91.44

91.44

106.68

106.68

121.92

121.92

137.16

137.16

91.44

106.68

121.92

137.16

91.44

106.68

121.92

137.16

91.44

106.68

121.92

137.16

91.44

106.68

121.92

137.16

91.44

106.68

121.92
7.4

4.2

6.0

9.8

5.2

5.3

5.4

9.1

3.8

4.4

6.0

8.6

2.8

3.9

5.2

9.5

2.4

3.6

5.6

8.9

3.1

4.1

6.6

8.7

8.8

8.8

4.2

4.2

5.6

5. 6

8.6

8.6

8.9

4.9

5.2

8.8

17.9

11.4

5.1

8. 5

16.4

12.0

9.2

8.7

22.6

15.9

12.2

10.0

21.5

18.4

14.4 


\begin{tabular}{|c|c|c|}
\hline 20MAR85 & 137.16 & 10.2 \\
\hline 28MAR8 5 & 91.44 & 19.6 \\
\hline 28MAR 85 & 106.68 & 18.2 \\
\hline 28MAR85 & 121.92 & 16.1 \\
\hline 28MAR85 & 137.16 & 11.0 \\
\hline 04APR85 & 91.44 & 21.5 \\
\hline 04APR 85 & 106.68 & 19.4 \\
\hline 04APR85 & 121.92 & 17.4 \\
\hline 04APR85 & 137.16 & 14.2 \\
\hline 14MAY85 & 91.44 & 14.5 \\
\hline 14MAY85 & 106.68 & 14.6 \\
\hline 14MAY85 & 121.92 & 13.9 \\
\hline 14MAY85 & 137.16 & 15.3 \\
\hline 22MAY85 & 91.44 & 19.3 \\
\hline 22MAY85 & 106.68 & 23.0 \\
\hline 22MAY85 & 121.92 & 15.8 \\
\hline 22MAY85 & 137.16 & 15.8 \\
\hline 30MAY85 & 91.44 & 13.2 \\
\hline 30MAY85 & 106.68 & 14.0 \\
\hline 30MAY85 & 121.92 & 13.5 \\
\hline 30MAY85 & 137.16 & 15.6 \\
\hline 06JUN85 & 91.44 & 12.9 \\
\hline 06JUN85 & 106.68 & 13.2 \\
\hline 06JUN85 & 121.92 & 13.2 \\
\hline 06JUN8j & 137.16 & 17.0 \\
\hline 14JUN85 & 91.44 & 10.9 \\
\hline 14JUN85 & 106.68 & 12.3 \\
\hline 14JUN85 & 121.92 & 12.8 \\
\hline 14JUN85 & 137.16 & 15.7 \\
\hline 16JUL85 & 91.44 & 6.1 \\
\hline 16JUL85 & 106.68 & 9.6 \\
\hline 16JUL85 & 121.92 & 10.7 \\
\hline 16JUL85 & 137.16 & 14.5 \\
\hline 29JUL85 & 91.44 & 4.7 \\
\hline 29JUL85 & 106.68 & 8.3 \\
\hline 29JUL85 & 121.92 & 9.7 \\
\hline 29JUL85 & 137.16 & 14.1 \\
\hline 13AUG85 & 91.44 & 7.2 \\
\hline 13 AUG 85 & 106.68 & 7.7 \\
\hline 13AUG85 & 121.92 & 9.0 \\
\hline $13 \mathrm{AUG} 85$ & 137.16 & 13.7 \\
\hline
\end{tabular}

- Type $=$ Crushed tuff $\quad$ Tube Number $=51$

$\begin{array}{lcc}\begin{array}{l}\text { Sampling } \\ \text { Date }\end{array} & \begin{array}{l}\text { Depth From } \\ \text { Surface (cm) }\end{array} & \begin{array}{l}\text { Volumetric } \\ \text { Moisture } \\ \text { Content (8) }\end{array} \\ \text { 22FEB84 } & 91.44 & 10.2 \\ \text { 22FEB84 } & 106.68 & 8.5 \\ \text { 22FEB84 } & 121.92 & 8.2 \\ \text { 22FEB84 } & 137.16 & 10.3 \\ \text { 04JUN84 } & 91.44 & 9.2\end{array}$




\begin{tabular}{|c|c|c|}
\hline 04JUN84 & 106.68 & 9.1 \\
\hline 04JUN84 & 121.92 & 8.4 \\
\hline 04JUN84 & 137.16 & 10.2 \\
\hline 24JUL84 & 91.44 & 7.1 \\
\hline 24JUL84 & 106.68 & 7.6 \\
\hline 24JUL84 & 121.92 & 8.0 \\
\hline 24JUL84 & 137.16 & 9.7 \\
\hline 22AUG84 & 91.44 & 5.4 \\
\hline 22AUG84 & 106.68 & 7.7 \\
\hline 22AUG84 & 121.92 & 7.6 \\
\hline 22AUG84 & 137.16 & 10.5 \\
\hline 12SEP84 & 91.44 & 5.5 \\
\hline 12SEP84 & 106.68 & 5.7 \\
\hline 12SEP84 & 121.92 & 6.6 \\
\hline 12SEP84 & 137.16 & 9.9 \\
\hline 180CT84 & 91.44 & 5.6 \\
\hline 180CT84 & 106.68 & 6.7 \\
\hline 180CT84 & 121.92 & 7.3 \\
\hline $180 \mathrm{CT} 84$ & 137.16 & 9.2 \\
\hline 07NOV84 & 91.44 & 12.7 \\
\hline 07NOV84 & 91.44 & 12.7 \\
\hline 07NOV84 & 106.68 & 8.2 \\
\hline 07NOV84 & 106.68 & 8.2 \\
\hline 07NOV84 & 121.92 & 6.5 \\
\hline 07Nov84 & 121.92 & 6.5 \\
\hline 07NOV84 & 137.16 & 9.2 \\
\hline 07Nov84 & 137.16 & 9.2 \\
\hline 06DEC84 & 91.44 & 11.3 \\
\hline 06DEC84 & 106.68 & 8.9 \\
\hline 06DEC84 & 121.92 & 7.2 \\
\hline 06DEC84 & 137.16 & 9.2 \\
\hline 04JAN8 5 & 91.44 & 17.5 \\
\hline 04JAN85 & 106.68 & 14.0 \\
\hline 04JAN8 5 & 121.92 & 7.9 \\
\hline 04JAN85 & 137.16 & 9.1 \\
\hline 11FEB85 & 91.44 & 15.5 \\
\hline 11FEB85 & 106.68 & 12.7 \\
\hline 11FEB85 & 121.92 & 11.2 \\
\hline 11FEB85 & 137.16 & 10.6 \\
\hline 15MAR85 & 91.44 & 22.7 \\
\hline 15MAR85 & 106.68 & 17.1 \\
\hline 15MAR85 & 121.92 & 13.5 \\
\hline 15MAR85 & 137.16 & 12.4 \\
\hline 20MAR85 & 91.44 & 21.2 \\
\hline 20MAR85 & 106.68 & 18.9 \\
\hline 20MAR85 & 121.92 & 16.7 \\
\hline 20MAR85 & 137.16 & 13.2 \\
\hline 28MAR85 & 91.44 & 19.2 \\
\hline 28MAR8 5 & 106.68 & 17.8 \\
\hline 28MAR85 & 121.92 & 17.7 \\
\hline 28MAR85 & 137.16 & 15.5 \\
\hline n4APR85 & 91.44 & 21.2 \\
\hline 04APR85 & 106.68 & 19.5 \\
\hline 04APR85 & 121.92 & 18.7 \\
\hline
\end{tabular}




\begin{tabular}{|c|c|c|}
\hline 04APR85 & 137.16 & 17.6 \\
\hline 14MAY85 & 91.44 & 14.1 \\
\hline 14MAY85 & 106.68 & 14.3 \\
\hline 14MAY85 & 121.92 & 14.9 \\
\hline 14MAY85 & 137.16 & 16.2 \\
\hline 22MAY85 & 91.44 & 14.7 \\
\hline 22MAY85 & 106.68 & 14.9 \\
\hline 22MAY85 & 121.92 & 17.9 \\
\hline 22MAY85 & 137.16 & 17.9 \\
\hline 30MAY85 & 91.44 & 13.3 \\
\hline 30MAY85 & 106.68 & 13.5 \\
\hline 30MAY85 & 121.92 & 14.3 \\
\hline 30MAY85 & 137.16 & 17.0 \\
\hline 06JUN85 & 91.44 & 12.4 \\
\hline 06JUN85 & 106.68 & 12.8 \\
\hline 06JUN85 & 121.92 & 13.7 \\
\hline 06JUN85 & 137.16 & 17.5 \\
\hline 14JUN85 & 91.44 & 11.6 \\
\hline 14JUN85 & 106.68 & 12.3 \\
\hline 14JUN85 & 121.92 & 13.1 \\
\hline 14JUN85 & 137.16 & 16.1 \\
\hline 16JUL85 & 91.44 & 7.9 \\
\hline 16JUL85 & 106.68 & 10.2 \\
\hline 16JUL85 & 121.92 & 10.7 \\
\hline 16JUL85 & 137.16 & 14.8 \\
\hline 29JUL85 & 91.44 & 6.0 \\
\hline 29JUL85 & 106.68 & 8.3 \\
\hline 29JUL85 & 121.92 & 9.9 \\
\hline 29JUL85 & 137.16 & 14.1 \\
\hline 13AUG85 & 91.44 & 9.8 \\
\hline 13AUG85 & 106.68 & 6.2 \\
\hline 13AUG85 & 121.92 & 8.8 \\
\hline 13AUG85 & 137.16 & 13.7 \\
\hline
\end{tabular}

